\title{
The Impact of Academic Discipline on University Teaching and Pedagogical Training Courses
}

\author{
Katarina Aškerc Veniger ${ }^{1}$ and Sebastian Kočar ${ }^{2}$ \\ ${ }^{1}$ Centre of the Republic of Slovenia for Mobility and European Educational and Training \\ Programmes \\ ${ }^{2}$ The Australian National University, ANU Centre for Social Research and Methods
}

\section{Abstract}

Professional development of university teachers in teaching, not only in research, has become an important topic in the development of higher education (HE) policies in recent years. Specific research on pedagogical development of university teachers remains limited, not taking into account academic disciplines and their impact on teachers' perceptions of different components of their teaching and training courses intended for their professional development. In this paper, we are presenting the differences among Slovenian teachers in different disciplines regarding their perception of teaching and their attitude towards pedagogical training courses (PTCs) with the results of an online survey study. Our findings show that teachers of soft sciences are more involved in PTCs than university teachers of hard sciences, except those from Health sub-discipline. Teachers of soft sciences, in comparison to those of hard sciences, generally perceive the quality of their own teaching as slightly higher, and they also have a slightly, but statistically significantly better attitude towards PTCs and teaching in general. Teachers from Health sub-discipline are generally more similar to soft sciences teachers than to hard sciences teachers in terms of different pedagogical dimensions studied. We can conclude that there is quite a clear distinction between teachers of soft sciences and teachers of certain hard sciences in their attitude and perception of different elements of university teaching and training courses in general (external heterogeneity). However, there 
is little separation between individual disciplines (internal homogeneity), which should be taken into account at least when introducing and implementing PTCs for teachers in different disciplines at institutional or national level.

Key words: academic disciplines; attitude towards university teaching; professional development; university teachers.

\section{Introduction}

Over the last 30 years, the image of universities as places devoted to knowledge production has increasingly changed. By the Bologna process and as a result of massification of $\mathrm{HE}$ and the increased social pressure on higher education institutions (HEIs), the primacy of research over teaching is becoming a matter of debate, which is also a part of a movement toward educational and pedagogical innovation (Endrizzi, 2011). However, teaching is instead regarded as taking time away from research, but "if we wish to improve the quality of education at universities /.../, the teaching skills of university professors must be improved" (Pleschova \& Simon, 2009, p. 246). Teacher training can be an essential factor for improving the quality of university education and for the construction of pedagogical excellence in HE (Duta, 2012; Esteves, 2008). There are significant differences between university teachers in different disciplines in their participation in different types of pedagogical training courses (PTCs), their professional development in general and in their previous formal pedagogical education (Aškerc \& Kočar, 2015). There is some research on disciplinary teaching specifics in higher education, but very little research on the pedagogical training of higher education teachers in different academic disciplines (Batanero \& Carmen, 2007; Kolari \& Savander-Ranne, 2002; Pleschova \& Simon, 2009). There is especially a lack of in-depth research on the relationships between disciplines, pedagogical training and focus on teaching versus research, and consequently, there is a lack of empirical evidence to support policy development of pedagogical training on the national level - according to disciplines. Therefore, the purpose of this study is to investigate the differences between the university teachers in different disciplines, with the focus on their attitude towards university teaching and PTCs in general.

\section{Teaching and Pedagogical Training Courses in Higher Education}

Quality assurance in university teaching has an essential role - it is maintained by developing and implementing training programmes ${ }^{1}$, including the development of coherent teaching skills of HE teaching staff and their evaluation (Mara \& Mara, 2011).

\footnotetext{
${ }^{1}$ When citing different authors, we keep the terms used in the primary source - consequently, besides the term pedagogical training courses (PTCs), the terms like training programs, pedagogical training(s), professional development programmes etc., are used. In our authorial text we always use PTCs, when talking about different forms of pedagogical courses or programmes for university teachers.
} 
Knight, Tait, and Yorke (2006) write about how professional development programmes should also have an impact on the system as a whole, and not only seek to change teachers. Thus, university teaching includes individual strategies for the training of the academic staff, strategies that involve students, strategies that involve other academic teachers, as well as strategies initiated at the university level (Knight et al., 2006). The study of teacher training in HE is a relatively new area of research (Pleschova \& Simon, 2009), while research on educational and pedagogical development remains limited (Endrizzi, 2011). Stes (2009), though, observes that instructional development for teachers in HE has become an important topic.

Teachers' motivation was found to be important in the teaching profession, wherein the intrinsic motivation is increased in case of a greater personal desire to pursue a career in the teaching profession (Mara \& Mara, 2011). Some authors present experienced teachers' development as related to their comfort with teaching, as well as to their knowledge and skills (Åkerlind, 2003). They focus on different factors, i.e. gender, career plans, career status and year of study, when verifying teachers' desire to be trained (Pleschova \& Simon, 2009). Also, they present relationship between training courses and teaching in HE (Camblin \& Steger, 2000; Postareff, LindblomYlänne, \& Nevgi, 2007). Even though Postareff et al. (2007) claim that desirable effects are brought only by long-term training programmes and that teachers' approaches to teaching change slowly, in general, almost all studies on the effect of PTCs have shown positive effects on academics' teaching and teachers and students alike (Coffey \& Gibbs, 2000; Pleschova \& Simon, 2009; Postareff et al., 2007). In their study, which was carried out over a long period and included 22 universities from eight countries, Gibbs and Coffey (2004) found out that training courses can improve various elements of teaching (according to students' evaluations). Thus, HE teachers who undergo PTCs (will) do a better job than those who did not take those courses (Trowler \& Bamber, 2005) and participation in PTCs can help teachers improve their students' learning. In some countries (e.g. Sweden, Australia and the UK) the introduction of compulsory training courses for university teachers is being considered, and some have already implemented such a policy. In Norway, all appointed lecturers should achieve 'basic pedagogical competence' by going through a training course of about 100 hours (3-4 weeks) (Varnava-Marouchou, 2010).

"HEIs are directly responsible for the pedagogical training of university teachers" (Mara \& Mara, 2011, p. 1413), wherein Pleschova and Simon (2009) found out that the longer the quality assurance has been operating in an EU member state, the more likely its HEIs are to offer training. Besides, the authors (Pleschova \& Simon, 2009, p. 246) presented interesting findings that "institutions that do well in research also find it more important to train their doctoral students in teaching methods /.../ (this is why) it is more appropriate to speak about the overall quality of educational institutions than to classify European universities into teaching and research institutions." According to Pleschova and Simon (2009), as much as two-thirds of the respondents in their 
research would like to acquire teaching skills. However, in most HEIs teaching remains an isolated and largely uncoordinated activity (Endrizzi, 2011), which could mean that informal training is the dominant approach in the current professional development practices (Knight et al., 2006). Marentič Požarnik and Lavrič (2015, p. 79) point out that competences of "teaching excellence" have to be (systematically and officially) developed during teachers' careers since they are not "in the genes" of HE teachers. Pedagogical competences can be somehow unsystematically and informally developed by self-study, learning from experience, or by imitating other teachers. However, some authors (Trigwell, Martin, Benjamin, \& Prosser, 2000) claim that officially supported learning is of a greater value since it includes an academic approach to teaching, similarly to the usual approach in research in different disciplines. "This agenda focuses not just on teaching but on teaching as scholarship” (Trigwel et al., 2000, p. 155).

\section{Training of University Teachers over Academic Disciplines}

Since there are different stages of teachers' careers or their professional pedagogical development and qualification (Kugel, 1993), different types of PTCs are also reasonable. Aškerc Veniger (2016) listed four different options of PTCs ${ }^{2}$, wherein Aškerc and Kočar (2015) found out that there are statistically significant differences in opinions and general participation of university teachers in different disciplines (ISCED groups) in different types of PTCs. Endrizzi (2011) also points out that training needs vary according to age, gender, seniority and discipline of a teacher. At the beginning of the career, the impact of teacher training varies slightly among disciplines (Stes et al., 2010). However, longer training processes result in more positive effects on teachers' conceptions of teaching and learning, and the impact of training (among disciplines) is heavily influenced by the length of the training period (Postareff et al., 2007).

Due to differences in participation in PTCs, as well as in attitude towards different PTCs regarding academic disciplines, with this paper we would like to show how significant the differences between the disciplines regarding participation and teachers' attitude towards PTCs (RQ1) are, and if there is any relation between the participation in PTCs and the attitude towards courses regarding different disciplines (RQ2).

Marentič Požarnik (2009) reports that the amount of independent study time participants needed to complete pedagogical course assignments in Slovenia varied from 10 to over 30 hours, with the average being about half of the contact time ( 24 hours versus 48 hours or 72 hours for the whole course). There are no policies, nor agreement about how much time should be required and offered for PTCs to Slovenian university teachers, especially in individual disciplines. The reason for that might be the fact that the issue of pedagogical qualification and training is not clearly defined in Slovenian HE legislation (Aškerc, 2014; Aškerc \& Kočar, 2015). While some

${ }^{2}$ 1) obligatory initial pedagogical training for all teachers, (2) obligatory initial pedagogical training for teachers with no previous pedagogical education, (3) obligatory follow-up training for all teachers (every few years), and (4) follow-up training only for teachers with bad results on student evaluations of teaching. 
teachers attend PTCs with assignments in the amount of 72 hours and more in case of some disciplines (i.e. the health and welfare group stands out positively), (informal) courses of short duration are generally offered to university teachers in Slovenia.

Since there are both differences in general participation in PTCs, as well as in the amount of time spent on training by university teachers in different disciplines, we would also like to find out how many PTCs an average teacher of a specific discipline has (RQ3).

\section{Pedagogical Competences of University Teachers across Academic Disciplines}

PTCs are an essential tool for the development of pedagogical competences of university teachers. Not only does pedagogical competence ${ }^{3}$ include the teaching skills and the scholarship of teaching, but it also goes (far) beyond them (Olatunji, 2013). Excellent university teachers know their subjects extremely well, they create a natural critical learning environment, teaching sessions are as important as research and scholarship to them, they can capture and monitor students' attention, students are treated fairly, they systematically evaluate their progress etc. (Bain, 2004). Suciu and Mâță (2011, pp. 411-412) regard teachers' "pedagogical competences in close connection with three important factors of education: educational achievement/ success/efficiency, professional development and societal change." Webler (2013) presents a list of key competences for teachers as reflective practitioners in HE: self-competence, social competence (it includes common social competences and special social competences of a teacher) and competence in one's discipline or subject. Endrizzi (2011, p. 1) summarises Rege Colet and Berthiaume (2009), who write that "the identity of the profession is also primarily a matter of allegiance to a particular discipline" since academics are researchers first, teachers second.

Stoecker (1993) cites Adams (1976), who writes that the influence of unique disciplinary attitudes, beliefs, and behaviours is so apparent to some that they have characterised the faculty as academic tribes. A metaphor of academic "tribes and territories" (Becher \& Trowler, 2001) is of great relevance in this context in relation to teaching and learning, and particularly in relation to staff development and academic competences in different disciplinary cultures, where the authors give an indication of which discipline is situated in which area $^{4}$. Similarly, three dimensions of the Biglan (1973) classification include the hard-soft dimension, the pure-applied dimension and the life-nonlife dimension, wherein a comparison of life and nonlife

\footnotetext{
${ }^{3}$ In the empirical part of this survey, sets of pedagogical competences are designed in accordance with the student evaluation questionnaire, which was valid in Slovenian $\mathrm{HE}$ at the time of data gathering.

${ }^{4}$ Hard-pure area (natural sciences), soft-pure area (humanities and pure social sciences), hard-applied area (technologies) and soft-applied area (applied social sciences).

${ }^{5}$ Mathematics, physics and chemistry are examples of pure hard sciences; history, arts, and aesthetics are pure soft sciences; medicine and engineering are examples of applied hard sciences, and examples of applied soft sciences are law or theology (Neumann et al., 2002).
} 
disciplines suggested that while life scholars were more socially connected, they were less interested and involved in teaching than nonlife faculty. Smart and Elton (1982, as cited in Stoecker, 1993) also found out that nonlife faculty reported more interest and time in teaching activities. Neumann, Parry, and Becher (2002) described the differences in teachers' structures of knowledge and general types of teaching method among hard, pure, soft, and applied sciences. ${ }^{5}$. There are general differences between disciplines in teaching and learning. Teachers in soft sciences generally spend more time in preparing courses, since the determination of knowledge content is less straightforward in comparison to hard sciences. Nevgi, Postareff, and LindblomYlänne (2004, p. 12) also found out that "the means of information transmission/ teacher-focused approach to teaching and conceptual change/student-focused approach to teaching varies significantly across the disciplines."

Since there are differences in approaches to teaching, types of teaching methods, knowledge transmission, etc. as a result of differences in disciplinary cultures, with our research we would like to investigate further how teachers in different disciplines perceive the importance of university teaching and how they self-evaluate the quality of their teaching (RQ4).

In general, it can be argued that the perceptions, requirements and expectations for teaching and pedagogical competences vary among various disciplines. However, we can also claim that there are no general common systematic approaches to PTCs in individual disciplines, including peculiarity of special or subject didactics. In preparing the future generation of political science professors, Pleschova and Simon (2009) found out that all PhD students who completed teacher training found the experience beneficial. Moreover, Batanero and Carmen (2007) found out that the initial pedagogical training of future statisticians was found to be very useful, but 60 teaching hours were reported to be insufficient amount of time to acquire the basic mastering of didactic knowledge. Similarly to the statistics discipline, many young people of today do not find engineering or science subjects/disciplines very attractive. Thus, the "ability to cope with new learning theories and master new teaching methods can present a solution in gaining better learning results and motivation" (Kolari \& Savander-Ranne, 2002, p. 59). Consequently, Finnish polytechnic teachers are required to have a formal pedagogical education and training of at least 35 credit units (Kolari \& Savander-Ranne, 2002). Medicine teachers find positive aspects of training as well, while Costa (2010) summarises that the need for changes in health teaching practice was recognised among several authors, including the need to train reflective teachers in health-area courses. The main advantage, indicated by more than 71 percent of respondents, was the possibility of being updated on teaching methods, e.g. teaching techniques/methods, the teaching-learning process, communication, learning evaluation and teacher-student relations.

Pedagogical training is in general recognised as beneficial in the majority, if not all, disciplines. However, each discipline seems to have its specifics in terms of the need for 
PTCs, as well as (the importance of) teaching practices. Therefore, the purpose of this study was also to come to a conclusion on the most significant differences in attitudes towards PTCs and university teaching between teachers in different disciplines, i.e. what separates them the most (RQ5).

\section{Methods}

This paper aims to investigate the effects of different university teachers' disciplines on various aspects of the teaching process, PTCs and university teaching in general, which was already presented in the theoretical part of this paper through existing studies and findings in the field. Before giving an overview of the design and results of the study, an outline of the research context will be presented.

The study was conducted in 2013 using a web survey as a method of data collection, which covered topics related to the Slovenian HE pedagogical environment, namely behavioural, attitudinal and perceptual dimensions of PTCs and university teaching. The data collection tool was designed, programmed online and later updated, having reviewed the pilot responses of 24 participants from the defined population. The e-link to the final questionnaire was then sent by e-mail to the members of the target group.

\section{Population and the Sample}

The population consisted of university teaching staff employed at the Slovenian HEIs (University of Ljubljana, University of Maribor, University of Primorska, University of Nova Gorica and smaller independent HEIs). The population was divided into the following groups: Full Professors, Associate Professors, Assistant Professors, Senior Lecturers, Lecturers, Lectors (language teachers), Assistants and Instructors. There were 8,763 employees who by definition fell within the population of the research (Statistical Office of the Republic of Slovenia, 2013). The aim was to avoid sampling by trying to cover as large part of the population as possible. Therefore, a major part of the population was invited to participate in the survey $(\mathrm{N}=5,650)$, and 513 respondents successfully filled out the questionnaire, which corresponds to $9.1 \%$ response rate and $5.9 \%$ sample rate. The sample consisted of units from various ISCED 1997 fields of education (2-digit level), which were later thematically classified into six distinctive ISCED 1-digit level groups or disciplines, i.e. Education, Humanities and Arts, Social Sciences, Natural Sciences, Engineering, Manufacturing and Construction, and Health and Welfare ${ }^{6}$.

\footnotetext{
${ }^{6}$ In the survey, nine groups of International Standard Classification of Education - ISCED 1997, which consists of 25 fields of education (UNESCO 2012), were merged into six groups or disciplines, as follows. The percentages for the respondents are added: 1) Education - $10.7 \%$ (14 Teacher training and education science); 2) Humanities and Arts - $15.6 \%$ (21 Arts, 22 Humanities); 3) Social Sciences - $26.1 \%$ (31 Social and Behavioural Science, 32 Journalism and Information, 34 Business and Administration, 38 Law, 81 Personal Services, 84 Transport Services, 86 Security Services); 4) Natural Sciences - 19.3 \% (42 Life Sciences, 44 Physical Sciences, 46 Mathematics And Statistics, 48 Computing, 6 Agriculture, 62 Agriculture, Forestry And Fishery, 64 Veterinary, 85 Environmental Protection); 5) Engineering, Manufacturing and Construction - 18.3 \% (52 Engineering and Engineering Trades, 54 Manufacturing and Processing, 58 Architecture and Building), and 6) Health and Welfare $-9.9 \%$ (72 Health,
} 
We emphasise the importance of extra caution when interpreting or using the survey data obtained with the low response rate. However, some researchers concluded that the data gained with a lower response rate can still provide accurate measurements (Horta, 2013) and other authors found out that higher response/completion rates are not always an indication of higher accuracy of results (Yeager, Krosnick, Chang, Javitz, Levendusky, Simpser, \& Wang, 2011). Besides, it was estimated that the response rates in web surveys are on average approximately $11 \%$ lower than those reported in studies using more traditional survey modes of data collection (Lozar Manfreda, Bosnjak, Berzelak, Haas, \& Vehovar, 2008). It is not insignificant that our survey was conducted among a highly specialised population, which usually have less time available. In this context, we believe that data acquired with our research still present an interesting and useful overview of the Slovenian situation in the field.

\section{Weighting of Data}

Based on the results of analysis of the demographic structure, due to non-response and due to under-coverage, we later recognised the need to weight the sample data by the teacher's title to make necessary adjustments in order to represent the population better. Comparing the population distribution and the sample distribution of variable teacher's title, we realised that Instructors and Assistants were significantly underrepresented, while Senior lecturers and Assistant Professors were significantly overrepresented. Since we noticed some notable differences among teachers with different titles in their attitudes, as well as in participation, the final results of our analyses could have been biased and therefore it was necessary to introduce a weighting factor. The variable was calculated from the known distribution of the population (see Statistical Office of the Republic of Slovenia, 2013) and the analysed distribution of the sample.

\section{Statistical Methods}

Data were analysed using SPSS 22.0 statistical software. We presented descriptive statistics such as frequencies, averages and measures of variability. To present the differences between disciplines, we performed the Chi-square test and the Independent samples t-test, carried out the Analysis of Variance and added effect size measures where required: Cohen's $d$ for effect sizes of two compared groups and Eta squared for effect sizes of more than two compared groups. We also used statistical methods for dimension reduction/creation of indices (Factor analysis - maximum likelihood with Varimax rotation), reliability analysis for newly constructed indices (Cronbach alpha) and for the creation of linear combinations of features which characterised or separated our analysed disciplines the most (Discriminant analysis). 76 Social Services).

\section{Results}

Firstly, we are presenting the differences in attitudes towards different kinds of PTCs between the teachers in different disciplines and their participation in courses 
(RQ1). The radar chart (Figure 1) visually presents the results, highlighting the differences between teachers in different disciplines. On the left-hand side of the chart, the participation comparisons between teachers in different academic disciplines in PTCs for university teachers are shown, and the rest of the chart presents their attitude, specifically how important teachers consider PTCs (for different purposes) to be. Percentages of those who agreed (4) or strongly agreed (5) on a 5-point scale with the statements about the importance of different types of PTCs were calculated.

It can be seen that there are some significant differences in the case of participation in PTCs for university teachers coming from different disciplines. Teachers in Health and Welfare group were the most included in PTCs for university teachers, followed by Social Sciences teachers. On the other hand, Natural Sciences teachers and teachers in Engineering, Manufacturing, Construction and Education had spent very little time for PTCs in the last ten years before the study.

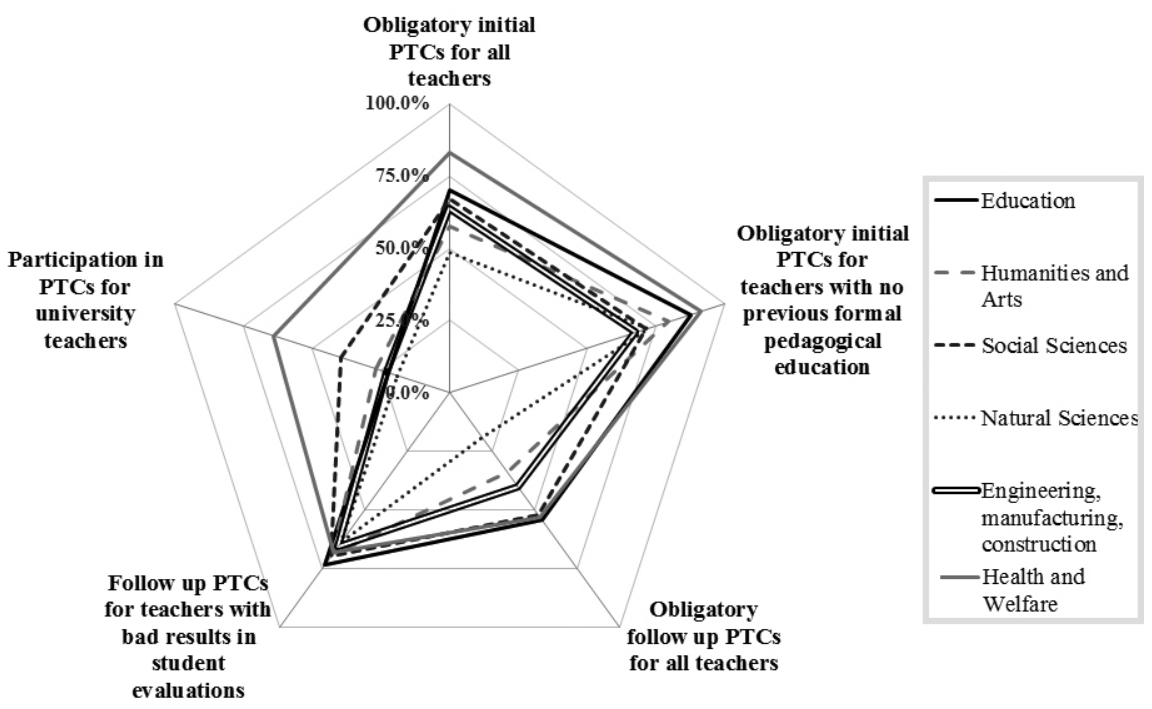

Figure 1. Differences in participation and attitudes towards PTCs

While comparing opinions of teachers in different academic disciplines on different kinds of PTCs, we came up with significant differences (Chi-square test, p values < .05), except for the follow-up PTCs for teachers with bad results in student evaluations of teaching ( $\mathrm{p}$-value $>.05$ ). Health and Welfare is the group which, in general, supports PTCs the most, especially obligatory initial PTCs for all university teachers and those teachers with no previous formal pedagogical education. Teachers in that discipline are then followed by the Education teachers, who showed the most support for the followup PTCs for teachers with bad results in student evaluations of teaching. Among all disciplines, Humanities and Arts, and especially Natural Sciences teachers, stand out as teachers who show relatively little support for PTCs, especially for obligatory PTCs 
for all university teachers, including both the initial courses and the follow up courses. Natural Sciences teachers, as well as Engineering, Manufacturing and Construction teachers, also stand out as the groups of teachers with the lowest percentages of participation in PTCs $(<25 \%)$.

We, therefore, wanted to estimate how much time an average university teacher of a particular discipline spent on PTCs in the number of hours (RQ3), taking into account both the differences in participation and the average length of training courses attended. Therefore, all respondents were included in the analysis, including those who have never participated in any PTCs.

Table 1

Average participation of university teachers in PTCs by academic discipline

\begin{tabular}{lcc}
\hline Discipline & N & $\begin{array}{c}\text { Average no. of hours/ } \\
\text { teacher }\end{array}$ \\
\hline Education & 57 & 13.59 \\
Humanities and Arts & 78 & 13.01 \\
Social Sciences & 126 & 17.12 \\
Natural Sciences & 105 & 7.57 \\
Engineering, Manufacturing and Construction & 99 & 7.33 \\
Health and Welfare & 47 & 16.17 \\
\hline Total & 513 & 12.17 \\
\hline
\end{tabular}

Table 1 presents results on hours being spent on PTCs by teachers' academic disciplines. There are two disciplines which stand out positively - Social Sciences and Health and Welfare with 17.12 hours and 16.17 hours, respectively. The average number of hours spent on attending training courses is by far the lowest in Natural Sciences and Engineering, Manufacturing and Construction (less than 8 hours, respectively). With the inclusion of all teachers/respondents (participants and nonparticipants of PTCs) from the sample in the analysis, the differences between disciplines are more clearly presented and highlighted, which also allows us to assume that PTCs are relatively unpopular in some disciplines.

Furthermore, we tried to establish how teachers in different disciplines in Slovenia perceive the importance of university teaching and how they self-evaluate the quality of their teaching (RQ4). In addition to the results presented for the attitudes towards individual PTCs (see Figure 1), we also tried to summarise how teachers in different disciplines perceive the importance of PTCs in general (RQ1). Firstly, we conducted a factor analysis (maximum likelihood) with 15 variables, related to either attitudes towards PTCs or teachers' attitudes towards their teaching in general. The analysis was executed to reduce the number of attitudinal and perceptual dimensions. Since the number of variables in the questionnaire used to measure attitudes towards PTCs and one's teaching in general was quite high, we established indices as constructs of indicators for further comparative analysis. The Kaiser-Meyer-Olkin (KMO) measure of sampling adequacy was .767, which is considered as acceptable (Kaiser \& Rice, 
1974). Table 2 below presents the rotated factor solution (Varimax rotation) with four extracted factors (condition: eigenvalue $>1$ ) and variables with loadings (condition: $>$.4) which represent both how the variables are weighted for each factor and the correlation between the variables and the factor.

Table 2

Rotated factor matrix (max. likelihood and Varimax with Kaiser normalization)

\begin{tabular}{|c|c|c|c|c|}
\hline & \multicolumn{4}{|c|}{ Factor } \\
\hline & 1 & 2 & 3 & 4 \\
\hline Q11.1 Obligatory initial PTCs for all teachers & .805 & & & \\
\hline $\begin{array}{l}\text { Q11.2 Obligatory initial PTCs for those with no previous formal pedagogical } \\
\text { education }\end{array}$ & .684 & & & \\
\hline Q11.3 Obligatory follow up PTCs for all teachers & .719 & & & \\
\hline $\begin{array}{l}\text { Q11.4 Follow up PTCs only for teachers with bad results in student } \\
\text { evaluations }\end{array}$ & .428 & & & .678 \\
\hline $\begin{array}{l}\text { Q11.5 Student evaluations as being a good measure of quality of one's } \\
\text { teaching }\end{array}$ & & & & .513 \\
\hline Q11.6 Certificates PTCs as an integral part of habilitation procedures & .720 & & & \\
\hline \multicolumn{5}{|l|}{$\begin{array}{l}\text { Q11.7 Teachers' satisfaction with the way pedagogical competence is } \\
\text { accessed }\end{array}$} \\
\hline Q12.1 Importance attributed to quality of lectures/seminars* & & & .725 & \\
\hline Q12.2 Importance attributed to using active forms and methods of work* & & & .633 & \\
\hline $\begin{array}{l}\text { Q12.3 Importance attributed to appropriate grading/evaluating of } \\
\text { students' work* }\end{array}$ & & & .530 & \\
\hline $\begin{array}{l}\text { Q12.4 Importance of attitude, availability of teachers/associates to talk with } \\
\text { and help students* }\end{array}$ & & & .578 & \\
\hline Q13.1 "My lectures are of high quality"*** & & .843 & & \\
\hline Q13.2"I use active forms and methods of work"*** & & .680 & & \\
\hline Q13.3“"My evaluation/grading of students' work is of high quality"*** & & .741 & & \\
\hline $\begin{array}{l}\text { Q13.4 "My availability to talk and help students and my relationship with } \\
\text { students is of high quality"** }\end{array}$ & & .608 & & \\
\hline Eigenvalue & 3.523 & 2.921 & 1.590 & 1.244 \\
\hline$\%$ of Variance & 23.49 & 19.47 & 10.60 & 8.30 \\
\hline
\end{tabular}

*... as one of university teachers' pedagogical competences.

**... teachers' perceptions of quality of their own teaching (in the broadest sense).

Scales: 5-point Likert scale (1 - Strongly disagree, 5 - Strongly agree) for Q11 variables, 7-point Likert scale (1 Not important at all, 7 - Extremely important) for Q12 and Q13 variables

Based on the results of factor analysis, we therefore created four distinctive indices as sums of indicators/variables. Since the loading for indicator Follow-up PTCs only for teachers with bad results in student evaluations of teaching is higher for Factor 4 than for Factor 1, we used it to create the 4th index. We carried out reliability analysis for each proposed index and the following ones were constructed, to be used in further analysis: 
1) importance of PTCs (Factor 1 variables, Cronbach's alpha .829),

2) perceived quality of one's own teaching (Factor 2 variables, Cronbach's alpha .816),

3) importance of quality of teaching in general (Factor 3 variables, Cronbach's alpha .709),

4) importance of follow-up PTCs as a result of poor student evaluations (Factor 4 variables, Cronbach's alpha .545).

The reliability analysis showed that, since Cronbach's alpha values for the first three indices were higher than .7, they could be used in further analysis as very reliable measures. The Cronbach's alpha value of the fourth index was slightly lower, but still close to .6, which means that the reliability of the instrument should be considered as barely acceptable (Ferligoj et al., 1995). We consequently conducted analysis of variance (ANOVA) with all four indices to overview the differences in the attitudes towards PTCs and one's teaching among teachers in six separate disciplines. We tested variables for normality and homogeneity; in case equal variances could not be assumed, we used an appropriate post-hoc test (Dunnett's C).

The results revealed that in general, teachers perceived PTCs as moderately important (total mean $=3.51$ on a 5-point scale). However, there are some differences in the importance of training courses between groups: Natural Sciences stand out as groups of teachers who consider PTCs slightly less important (mean $=3.19)$, while Health and Welfare teachers consider them somewhat more important (mean $=3.87$ ). The findings are by no surprise very similar to the results presented in Figure 1. The effect size, as a quantitative measure of the strength of differences, was measured with $\eta^{2}$ (Eta squared), and the value equals .060, which means that the effect size is medium (Cohen, 1988).

On average, teachers perceive the quality of their teaching (in the broadest sense) as quite high (total mean $=5.63$ on a 7-point scale). Again, there are some statistically significant differences between groups in the perceived quality of their teaching. The effect size statistics $\eta^{2}$ equals .049, which means that the effect size is again medium (Cohen, 1988). Natural Sciences teachers again stand out since they believe that the quality of their teaching is slightly lower. On the other hand, especially Social Sciences and Education discipline teachers have a better opinion about the quality of their teaching.

Lastly, the results showed that pretty much all the teachers in different disciplines believe that quality of teaching is very important (means between 6.03 and 6.29 on a 7 -point scale). There might be some differences between disciplines in the importance of the quality of teaching (ANOVA test $\mathrm{p}$ value $<.05$ ), but a post-hoc test revealed that there were no notable differences between groups. Besides, the results show that there are no statistically significant differences between teachers in different disciplines in the importance of follow up PTCs for teachers with bad results in student evaluations.

The results showed significant differences in the reported importance of training courses between teachers in different disciplines. Therefore we wanted to go even 
deeper into the data to establish if there were any relations between the participation in and the attitudes towards PTCs (RQ2) in general, as well as in different academic disciplines.

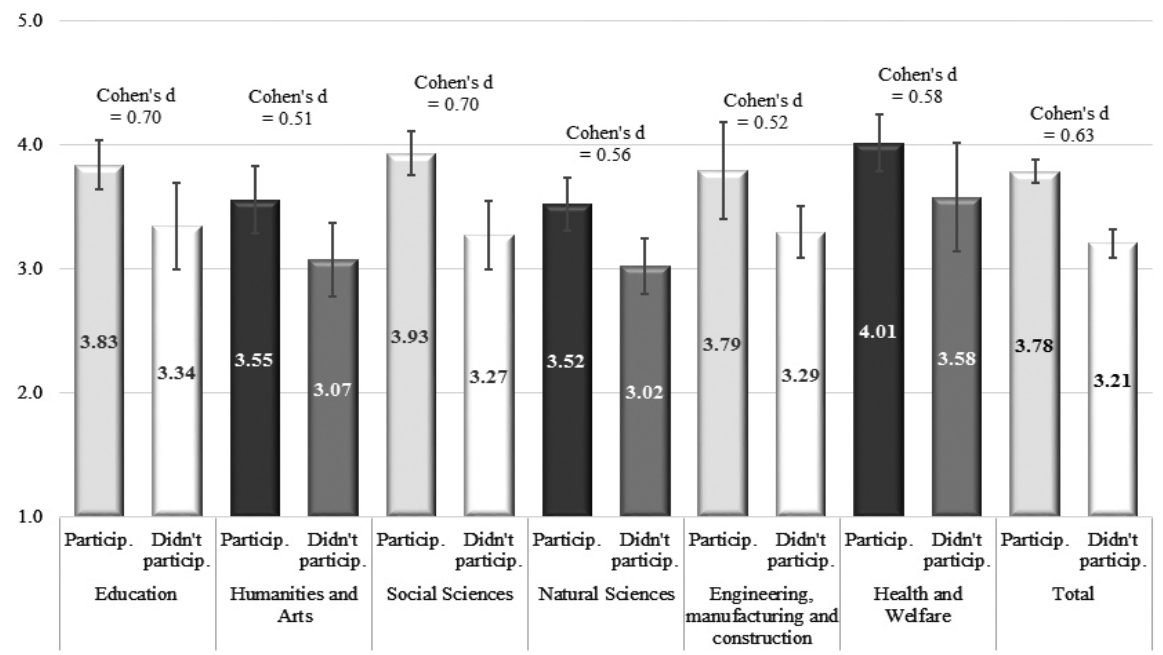

Figure 2. The importance of PTCs in different disciplines based on previous participation in pedagogical training

The results in Figure 2 show that, in general, there are statistically significant differences in the attitudes towards PTCs between those teachers who have and those who have not attended those courses. The effect size, as a quantitative measure of the strength of differences, was measured with Cohen's d, and the value for all teachers in all disciplines was .63, which means that the effect size was medium (Cohen, 1962). That means that those teachers who have personally experienced PTCs, believe to a greater extent that the PTCs are important. The differences between participants and non-participants in the individual disciplines are, on the other hand, not statistically significant in all cases, which could also be attributed to smaller sizes of disciplinary subsamples. The disciplines with differences, not statistically significant at $\alpha=.05$, are Education and Health and Welfare. On the other hand, the disciplines with statistically significant differences at $\alpha=.05$, but not at $\alpha=.01$, are Humanities and Arts and Engineering, Manufacturing and Construction. The only two disciplines with significant differences (at $\alpha=.01$ ) are therefore Social Sciences and Natural Sciences. The effect sizes, measured with Cohen's d, were .70 and .56, respectively, which means that the effect sizes are between medium and large (Cohen, 1962).

To extend and generalise these findings, we wanted to conclude our study by emphasizing the most important differences in the attitudes between teachers in different disciplines towards PTCs and (quality of) their teaching (RQ5). In the previous paragraphs, we concluded that teachers in Natural Sciences and Engineering, Manufacturing and Construction, as traditionally hard sciences, are less involved in pedagogical training and have slightly different attitudes towards teaching and PTCs. 
On the other hand, in those terms, teachers in Health and Welfare (with the vast majority of them working in Health sub-field) seemed to be more similar to soft than hard sciences teachers. Using those findings, we classified disciplines (from the original two-digit ISCED 2011 variable), into (1) soft sciences (pure and applied), (2) hard sciences (pure and applied, excluding Health sub-discipline), and (3) Health, based on the Revisited Biglan Classification (Stoecker, 1993). We carried out discriminant analysis to highlight the most significant differences between the groups of disciplines, trying to find a linear combination of features which characterises or separates the groups the most and to present results visually.

Table 3

Discriminant analysis coefficient for newly created index variables

\begin{tabular}{|c|c|c|c|c|}
\hline \multirow{3}{*}{ Variable/index } & \multicolumn{2}{|c|}{$\begin{array}{l}\text { Standardized } \\
\text { coefficients }\end{array}$} & \multicolumn{2}{|c|}{$\begin{array}{l}\text { Structure } \\
\text { coefficients }\end{array}$} \\
\hline & Function & Function & Function & Function \\
\hline & 1 & 2 & 1 & 2 \\
\hline Importance of PTCs & .764 & -.649 & $.615^{*}$ & -.465 \\
\hline Importance of quality of teaching in general & .208 & .010 & $.446^{*}$ & .200 \\
\hline Perceived quality of one's own teaching & .593 & .729 & .632 & $.757^{*}$ \\
\hline $\begin{array}{l}\text { Importance of follow-up PTCs as a result of bad } \\
\text { results in student evaluations }\end{array}$ & -.472 & .501 & -.133 & $.287^{*}$ \\
\hline Eigenvalue & .107 & .007 & & \\
\hline$\%$ of the variance of the discriminant model & 93.6 & 6.4 & & \\
\hline Canonical correlation & .311 & .085 & & \\
\hline Chi-square & 55.510 & 3.692 & & \\
\hline Chi-square statistics p value (Sig.) & $<.001$ & .297 & & \\
\hline
\end{tabular}

Table 3 displays both standardised coefficients and structure coefficients for the most significant discriminant functions, as well as their eigenvalues, the percentage of the variance explained, canonical correlations, and chi-square statistics with the significance of the discriminant functions. It must be noted that the eigenvalues are quite low (namely .107 and .007), which means that the differences between university teachers in different disciplines are small. Moreover, regarding the percentage of the variance, calculated as the proportion of the function's eigenvalue to the sum of all the eigenvalues, the first function is explaining most of the variance $(93.6 \%)$ of our discriminant model, but the second function is explaining only $6.4 \%$ of the variance of the model. The first function should, therefore, also due to a low eigenvalue and high significance of the second discriminant function ( $\mathrm{p}$ value $>.05$, testing that the canonical correlation of the given function is equal to zero), be considered as the only real separator of the groups. The function has the highest coefficient values for Importance of PTCs and Perceived quality of one's teaching; therefore, we can simply name it Importance of PTCs and quality of own teaching. 


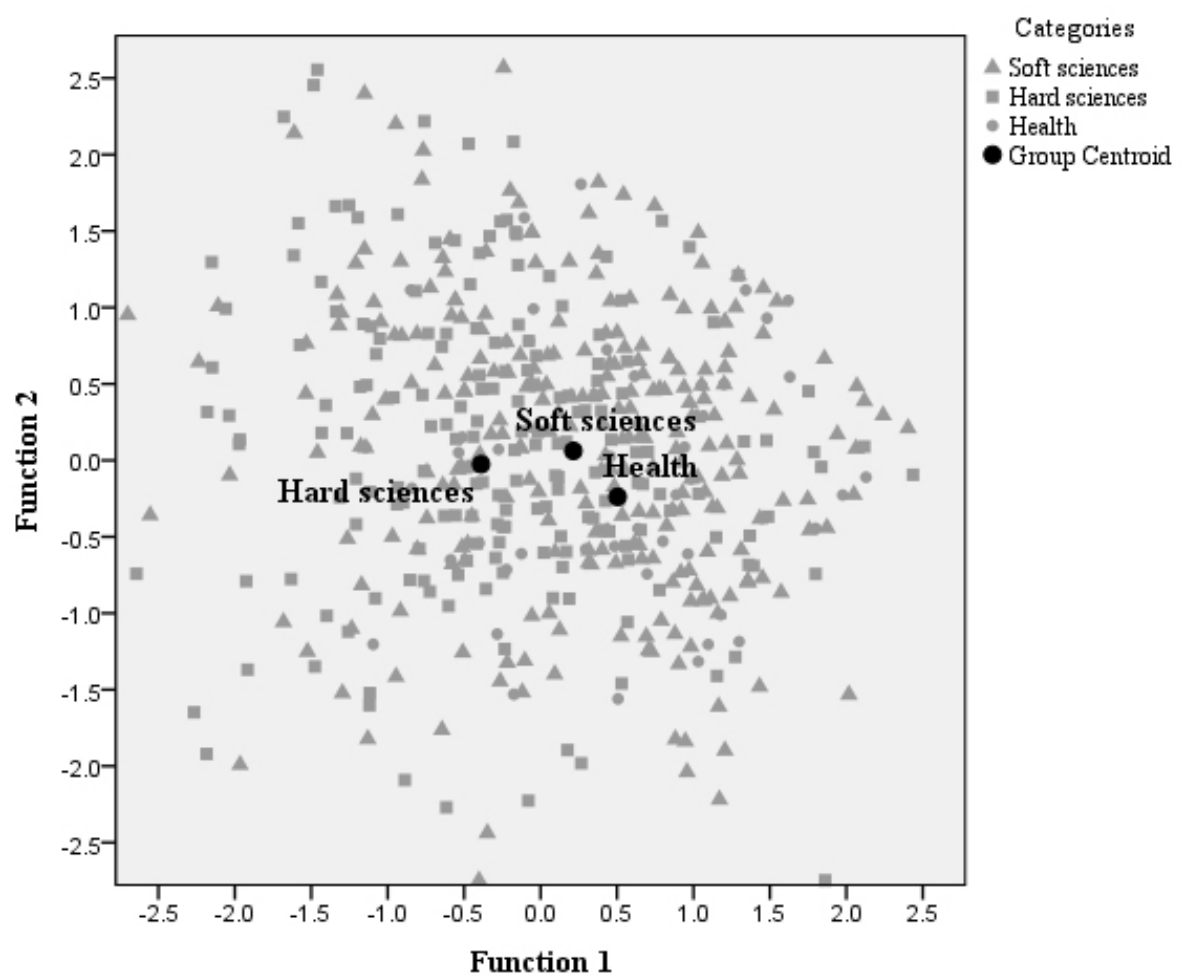

Figure 3. Canonical discriminant functions

Figure 3 shows Function 1 and Function 2 values for all units, as well as group centroids, which are averages of independent group units' values and display how groups are separated. We can conclude that there is no clear distribution, as we could find individual units, members of different groups/disciplines, spread all across the presented plot, although with the majority of Health units having Function 1 values higher than 0 . There are still some statistically significant differences, as shown by the group centroids. As already mentioned, the only function that clearly separates groups is Function 1 named Importance of PTCs and quality of own teaching. The disciplines with the lowest Function 1 centroid values are hard sciences (Natural Sciences and Engineering, Manufacturing and Construction) and the discipline with the highest Function 1 centroid value is Health (as Health and Welfare hardscience sub-discipline). The centroid for soft sciences (Education, Humanities and Arts, Social Sciences) is located in between, but slightly closer to the Health centroid than to the hard sciences centroid regarding its Function 1 value. We can, therefore, conclude that the soft sciences (as well as Health) have a better attitude towards PTCs and evaluate the quality of their teaching as higher. But we should emphasise that although the differences are statistically significant, they are quite small, and the derived discriminant functions are relatively weak predictors of group memberships. 


\section{Discussion}

Professional development of academics as university teachers, thus, has become an important topic in HE policies, following also the latest documents within Bologna process (European Standards and Guidelines, 2015; Yerevan Communique, 2015; etc.). However, specific research on the pedagogical development of university teachers remains limited, especially when taking into account academic disciplines and their impact on teachers' perceptions of different components of university teaching and their professional development as university teachers. In this context, with this research, we have found out that there are significant differences among Slovenian teachers in different disciplines in their attitudes towards PTCs and their perception of the quality of university teaching.

We can conclude that the disciplines differ the most in the behavioural dimension. In general, teachers in Social Sciences and Health and Welfare disciplines were more included in PTCs than teachers in other disciplines, judging by the measured average number of hours of PTCs per teacher of a particular discipline. Teachers of traditionally hard sciences, like Natural Sciences and Engineering, Manufacturing and Construction, were, on the other hand, significantly less involved in PTCs. Also, no teachers in any of the disciplines were on average involved in PTCs for more than 17 hours in the last ten years. As Stes et al. (2010) pointed out, the impact of teacher training varies slightly among disciplines at the beginning of their career, while longer training processes cause a more positive impact of training courses (Postareff et al., 2007). As they found out, programmes of longer duration (1-year long or at least 30 ECTS long programme) ensure more possibilities to affect teachers' pedagogical thinking and conceptions of teaching and learning. On the other hand, shorter courses may cause uncertainty about teachers' teaching skills. In our survey, the latter could be connected to results in the attitudinal dimension of respondents to PTCs, which are presented in the next paragraph (Postareff et al., 2007).

Teachers in different disciplines are distinguished in the attitudinal dimension, since in general, teachers in soft sciences (specifically Education) and Health and Welfare generally support obligatory PTCs (especially those for all teachers) more than teachers in certain hard sciences, specifically Natural Sciences. We discovered a relation between the mentioned dimensions, namely between the participation in and the attitudes towards different kinds of PTCs in individual disciplines and for certain types of training courses. Those who participated in training courses (although with a low number of hours on average), have in general a better attitude towards obligatory initial training courses for almost all disciplines. On the other hand, participation in PTCs does not affect the attitude of university teachers in Education and Health and Welfare disciplines at all. For the Education discipline teachers, the latter could be a consequence of their perception that they have already gained adequate knowledge of teaching. They had previously acquired (in their opinion) relevant expertise for 
teaching at primary or secondary school levels or in adult education, which they could consider as appropriate and sufficient for teaching at the HE level as well.

Besides, we found out that teachers in different disciplines differ to a certain degree in their perception of the quality of their teaching (in the broadest sense of the concept). In general, teachers perceive the quality of their teaching as quite high, wherein teachers of soft sciences, in comparison with teachers of certain hard sciences (especially Natural Sciences), perceive the quality of their teaching as slightly higher. Furthermore, we wanted to highlight the most significant differences among teachers in different disciplines (grouped) in their perceptions and attitudes towards teaching in general, as well as towards participation in PTCs. The results obtained supported all previous findings that teachers of soft sciences have better attitudes, especially towards PTCs and university teaching in general than teachers of hard sciences, but again it has to be pointed out that the differences are still relatively minor. The latter findings could be at least partly in line with Neumann's et al. (2002) description of differences among teachers of hard, pure, soft, and applied sciences, since teachers of soft sciences generally spend more time in preparing courses. That could consequently at least slightly impact their perception of the quality of their teaching, as well as their attitudes towards PTCs, which could present the path to a better organisation and implementation of lectures and to a higher quality of university teaching in general.

\section{Conclusions}

In accordance with our findings, we can conclude that there is quite a clear distinction between teachers of soft sciences and teachers of hard sciences (except for Health sub-discipline) in their participation in and their attitudes towards university teaching (in general) and more specifically towards PTCs. Thus, we can claim that, to some degree, our results support the findings of some other authors (Adams, 1976; Batanero \& Carmen, 2007; Becher \& Towler, 2001; Biglan, 1973; Carril, Sanmamed, \& Sellés, 2013; Costa, 2010; Kolari \& Savander-Ranne, 2002; Neumann et al., 2002; Nevgi et al., 2004; Pleschova \& Simon, 2009; Smart \& Elton, 1982; Stoecker, 1993), whose research was mainly focused on characteristics of teachers in specific disciplines themselves or on more common differences among teachers in different disciplines. In our case, the most notable differences were identified in teachers' behavioural dimension (participation in PTCs), which was followed by the attitudinal dimension (their attitude towards PTCs, as well as the importance of quality of university teaching in general). Besides, there are also significant, but minor differences in teachers' perceptual dimension, which includes teachers' perceptions of the quality of their teaching.

However, a significant limitation of our research has to be pointed out, since all the results and analyses are based only on the data collected with an online questionnaire, without teachers' more in-depth explanations and interpretations of their conceptions. An apparent difference in attitudes between lecturers from soft and hard sciences 
should be later on analysed in the context of underlying factors, which may relate to the status of respective disciplines. This status may be related to different social perceptions of teachers in different disciplines or underlying knowledge codes, etc. Also, the results cannot be generalised widely to HE populations beyond Slovenian higher education area. With further research, it would be worthwhile to carry out qualitative interviews with university teachers in different disciplines to substantively supplement and complement the existing data with their explanations of their perception of various elements of university teaching and PTCs, including their social perceptions, knowledge codes, etc. Besides, the extension of the research to other countries could bring more in-depth insight into the backgrounds of apparent differences among university teachers in different disciplines.

Although our research is based mainly on teachers' opinions about university teaching and PTCs obtained with a questionnaire, we believe that it already brings important policy implications and added value in creating different institutional as well as national policies, standards, regulations and also concrete practices in the field of (quality) university teaching, including professional staff development. Since there are observed differences between teachers in different disciplines in their behavioural, attitudinal and perceptual dimensions of training courses and university teaching, the latter should be taken into account at least when introducing and implementing PTCs at an institutional or national level for teachers in different disciplines.

\section{References}

Åkerlind, G. S. (2003). Growing and developing as a university teacher: Variation in meaning. Studies in Higher Education, 28(4), 375-90. https://doi.org/10.1080/0307507032000122242

Aškerc, K. (2014). Zakonodajni vidiki pedagoškega dela visokošolskega učnega osebja. Didactica Slovenica - Pedagoška Obzorja, 29(3-4), 170-181.

Aškerc Veniger, K. (2016). University teachers' opinions about higher education pedagogical training courses in Slovenia. CEPS Journal, 6(4), 141-161.

Aškerc, K., \& Kočar, S. (2015). Teaching and the Pedagogical Training of University Teaching Staff - Practice and Opinions according to the Slovenian Higher Education Legislation. Education Inquiry, 6(2), 159-175. https://doi.org/10.3402/edui.v6.25591

Aškerc, K., \& Kočar, S. (2016). Pedagogical training of higher education teachers and associates, 2013 [data file]. Slovenia, Ljubljana: Aškerc, Katarina in Sebastian Kočar; [production], 2013. Slovenia, Ljubljana: University of Ljubljana, Social Science Data Archives [distribution], 2016.

Bain, K. (2004). What the Best College Teachers Do. Cambridge, MA: Harvard University Press. Batanero, C., \& Díaz, C. (2007). Training Future Statisticians to Teach Statistics. Statistique et Enseignement, 1(1), 5-20. 
Becher, T., \& Trowler, P. R. (2001). Academic Tribes and Territories: Intellectual enquiry and the cultures of disciplines (2nd ed.). Buckingham: Open University Press/SRHE.

Biglan, A. (1973). The characteristics of subject matter in different academic areas. Journal of Applied Psychology, 57(3), 195-203. https://doi.org/10.1037/h0034701

Camblin, L., \& Steger, J. (2000). Rethinking Faculty Development. Higher Education, 39(1), 1-18. https://doi.org/10.1023/A:1003827925543

Coffey, M., \& Gibbs, G. (2000). Can academics benefit from training? Some preliminary evidence. Teaching in Higher Education, 5(3), 385-389. https://doi.org/10.1080/713699136

Cohen, J. (1962). The statistical power of abnormal—social psychological research: A review. Journal of Abnormal and Social Psychology, 65, 145-153. https://doi.org/10.1037/h0045186

Cohen, J. (1988). Statistical power analysis for the behavioral sciences (2nd ed.). Hillsdale, NJ: Erlbaum.

Costa, N. M. S. C. (2010). Pedagogical Training of Medicine Professors. Rev. Latino-Am. Enfermagem, 18(1), 102-108. https://doi.org/10.1590/S0104-11692010000100016

Duta, N. V. (2012). Professional development of academics teachers - Reflections on participation in training programs. In International conference of scientific paper, Brasov, 24-26 May 2012. Retrieved from http://www.afahc.ro/ro/afases/2012/socio/2.2/Duta \%20Nicoleta.pdf

Endrizzi, L. (2011). Learning how to teach in Higher education: a matter of Excellence. IFÉ. Current literature review in education, 64, 1-23.

Esteves, M. (2008). Towards the pedagogical excellence of higher education. Sísifo. Educational Sciences Journal, 7, 99-106.

Ferligoj, A., Leskošek K., \& Kogovšek, T. (1995). Zanesljivost in veljavnost merjenja. Metodološki zvezki 11. Ljubljana: Fakulteta za družbene vede.

Gibbs, G., \& Coffey, M. (2004). The impact of training of university teachers on their teaching skills, their approach to teaching and the approach to learning of their students. Active Learning in Higher Education, 5(1), 87-100. https://doi.org/10.1177/1469787404040463

Horta, H. (2013). Deepening our Understanding of Academic Inbreeding Effects on Research Information Exchange and Scientific Output: New Insights for Academic Based Research. Higher Education, 65(4), 487-510. https://doi.org/10.1007/s10734-012-9559-7

International Standard Classification of Education ISCED 2011. Retrieved from http://www. uis.unesco.org/Education/Documents/isced-2011-en.pdf.

Kaiser, H. F., \& Rice, J. (1974). Little Jiffy Mark IV. Educational and Psychological Measurement, 34, 111-117. https://doi.org/10.1177/001316447403400115

Knight, P. T., Tait, J., \& Yorke, M. (2006). The professional learning of teachers in higher education. Studies in Higher Education, 31(3), 319-339. https://doi. org/10.1080/03075070600680786

Kolari, S., \& Savander-Ranne, C. (2002). Does Pedagogical Training Benefit the Engineering Educator? Global Journal of Engineering Education, 6(1), 59-70.

Kugel, P. (1993). How Professors Develop as Teachers. Studies in Higher Education, 18(3), 315-328. https://doi.org/10.1080/03075079312331382241 
Lozar Manfreda, K., Bosnjak, M., Berzelak, J., Haas, I., \& Vehovar, V. (2008). Web surveys versus other survey modes: a meta-analysis comparing response rates. International Journal of Research in Marketing, 50(1), 79-104. https://doi.org/10.1177/147078530805000107

Mara, D., \& Mara, E. L. (2011). Didactical competences formed for academic career. Procedia Social and Behavioral Sciences, 15, 1410-1414. https://doi.org/10.1016/j.sbspro.2011.03.303

Marentič Požarnik, B. (2009). Improving the quality of teaching and learning in higher education through supporting professional development of teaching staff. Napredak, 150(3-4), 341-359.

Marentič Požarnik, B., \& Lavrič, A. (2015). Fostering the Quality of Teaching and Learning by Developing the "Neglected Half" of University Teachers' Competencies. CEPS Journal, 5(2), 73-93.

Muñoz-Carril, P.C., González-Sanmamed, M., \& Hernández-Sellés, N. (2013). Pedagogical roles and competencies of university teachers practicing in the e-learning environment. International Review of Research in Open and Distance Learning, 14(3), 462-487. https:// doi.org/10.19173/irrodl.v14i3.1477

Neumann, R., Parry, S., \& Becher, T. (2002). Teaching and Learning in their Disciplinary Context: a conceptual analysis. Studies in Higher Education, 27(4), 405-417. https://doi. org/10.1080/0307507022000011525

Nevgi, A., Postareff, L., \& Lindblom-Ylänne, S. (2004). The effect of discipline on motivational and self-efficacy beliefs and on approaches to teaching of Finnish and English University teachers. Paper presented at SIG Higher Education conference, June 18-21, 2004.

Olatunji, M. O. (2013). Ensuring and promoting the pedagogical competence of university lecturers in Africa. Journal of Educational and Instructional Studies in the World, 3(3), 73-85.

Pleschova, G., \& Simon, E. (2009). Teacher Training for Political Science PhD Students in Europe Determinants of a Tool for Enhanced Teaching in Higher Education. Journal of Political Science Education, 5, 233-249. https://doi.org/10.1080/15512160903038116

Postareff, L., Lindblom-Ylänne, S., \& Nevgi, A. (2007). A follow-up study of the effect of pedagogical training on teaching in higher education. Higher Education, 56, 29-43. https:// doi.org/10.1007/s10734-007-9087-z

Rege Colet, N., \& Berthiaume, D. (2009). 'Savoir ou être? savoirs et identités professionnels chez les enseignants universitaires'. In R. Hofstetter, \& B. Schneuwly (Eds.), Savoirs en (trans)formation: au coeur des professions de l'enseignement et de la formation (pp. 137-162). Bruxelles: De Boeck.

Standards and Guidelines for Quality Assurance in the European Higher Education Area (2015). Retrieved from http://www.enqa.eu/wp-content/uploads/2015/11/ESG 2015.pdf

Statistical Office of the Republic of Slovenia (2013). Retrieved from http://www.stat.si/StatWeb/ en/home

Stes, A., Coertjens, L., \& Van Petegem, P. (2009). Instructional development for teachers in higher education: impact on teaching approach. Higher Education, 60(2), 187-204. https:// doi.org/10.1007/s10734-009-9294-x

Stoecker, J. (1993). The Biglan Classification Revisited. Research in Higher Education, 34(4), 451-464. https://doi.org/10.1007/BF00991854 
Suciu, A. I., \& Mâță, L. (2011). Pedagogical Competences - The Key to Efficient Education. International Online Journal of Educational Sciences, 3(2), 411-423.

Trigwell, K., Martin, E., Benjamin J., \& Prosser, M. (2000). Scholarship of Teaching: a model. Higher Education Research \& Development, 19(2), 155-168. https://doi. org/10.1080/072943600445628

Trowler, P., \& Bamber, R. (2005). Compulsory Higher Education Teacher Training: Joinedup policies, institutional architectures and enhancement cultures. International Journal for Academic Development, 10(2), 79-93. https://doi.org/10.1080/13601440500281708

Varnava-Marouchou, D. (2010). Can Faculty Conceptions of Teaching Influence Faculty Professional Development? New Horizons for Learning, VIII(2). Retrieved from file://D:/ Dokumenti/Downloads/49-49-1-PB.pdf

Webler, W. D. (2013). Was bedeuted die Fahigkeit, "professionell” an Hochschulen zu lehrnen? Ein konstitutives Element des Berufsbildes der Hochschullehrer/innen. In N. AuferkorteMichaelis et al. (Eds.), Personal- und Organisationsentwicklung in Einrichtungen der Lehre und Forschung (pp. 10-15). Bielefeld: Universitäts Verlag Webler.

Yeager, D. S., Krosnick J. A., Chang L., Javitz H., Levendusky M. S., Simpser A., \& Wang R. (2011). Comparing the Accuracy of RDD Telephone Surveys and Internet Surveys Conducted with Probability and Non-Probability Samples. Public Opinion Quarterly, 75(4), 709-47. https://doi.org/10.1093/poq/nfr020

Yerevan Communique (2015). Retrieved from http://www.ehea.info/Uploads/ SubmitedFiles/5 2015/112705.pdf

\section{Katarina Aškerc Veniger}

Centre of the Republic of Slovenia for Mobility and European Educational and Training Programmes

Ob železnici 30 a, 1000 Ljubljana, Slovenia

katarina.askerc-veniger@cmepius.si

\section{Sebastian Kočar}

The Australian National University, ANU Centre for Social Research and Methods 13 Ellery Crescent, ANU Campus, Canberra, 2601 ACT, Australia sebastian.kocar@anu.edu.au 


\section{Utjecaj akademskih disciplina na nastavu na sveučilišnoj razini i na pedagošku izobrazbu}

\section{Sažetak}

Stručno usavršavanje sveučilišnih nastavnika u području vođenja nastavnog procesa, a ne samo u području istraživačkog rada, postalo je u posljednjih nekoliko godina važna tema u razvoju strategije visokog obrazovanja. Postoji relativno ograničen broj istraživanja koja se bave isključivo pedagoškim usavršavanjem sveučilišnih nastavnika, ne uzimajući u obzir akademske discipline i njihov utjecaj na način na koji nastavnici percipiraju različite sastavnice nastavnog procesa koji vode i pedagošku izobrazbu koja je namijenjena njihovu stručnom usavršavanju. U ovom radu prikazujemo razlike izmedu slovenskih nastavnika iz različitih akademskih disciplina sobzirom na njihovo shvaćanje nastavnog procesa i stavove prema pedagoškoj izobrazbi, s pomoću rezultata istraživanja provedenog putem online upitnika. Naši rezultati pokazuju da su nastavnici iz područja mekih znanosti više uključeni u oblike pedagoške izobrazbe od sveučilišnih nastavnika iz područja tvrdih znanosti, osim onih iz poddiscipline $z$ dravstvo. Nastavnici iz područja mekih znanosti, u usporedbi s nastavnicima iz područja tvrdih znanosti, uglavnom smatraju da je kvaliteta njihova nastavnog procesa nešto bolja, a također imaju i malo, ali statistički znatno bolji stav prema pedagoškoj izobrazbi i nastavnom procesu uopće. Nastavnici iz zdravstvene poddiscipline uglavnom su sličniji nastavnicima iz područja mekih znanosti nego onima iz tvrdih znanosti kada se radi o različitim pedagoškim dimenzijama koje su se u istraživanju analizirale. Možemo zaključiti da postoji jasna razlika između nastavnika iz područja mekih i nastavnika iz područja tvrdih znanosti u stavovima i poimanju različitih elemenata nastavnog procesa na sveučilišnoj razini i pedagoškoj izobrazbi općenito (vanjska heterogenost). Međutim, postoji mala razlika izmedu pojedinačnih disciplina (unutarnja homogenost) koju bi trebalo uzeti u obzir kada se uvodi i provodi pedagoška izobrazba za nastavnike u različitim disciplinama na institucionalnoj ili nacionalnoj razini.

Ključne riječi: akademske discipline; stav prema nastavi na sveučilišnoj razini; stručno usavršavanje; sveučilišni nastavnici. 


\section{Uvod}

U posljednjih 30 godina uvelike se promijenio stav prema sveučilištima kao mjestima koja su usredotočena na proizvodnju znanja. Zbog Bolonjskog procesa sve je veća stopa pohađanja visokog obrazovanja i sve je veći društveni pritisak na institucije visokog obrazovanja, pa se počelo postavljati pitanje zaslužuje li istraživački rad prednost nad nastavnim procesom, što je također pomak prema obrazovnim i pedagoškim inovacijama (Endrizzi, 2011). Međutim, umjesto toga, smatra se da nastavni proces oduzima vrijeme koje bi se trebalo potrošiti na istraživanje, ali „ako želimo poboljšati kvalitetu obrazovanja na sveučilištima /.../, neophodno je razviti nastavničke vještine sveučilišnih profesora" (Pleschova i Simon, 2009, str. 246). Pedagoška izobrazba nastavnika može biti ključni faktor u unaprjeđenju kvalitete nastave na sveučilišnoj razini i u razvoju pedagoške izvrsnosti u visokom obrazovanju (Duta, 2012; Esteves, 2008). Postoje važne razlike među sveučilišnim nastavnicima iz različitih akademskih disciplina s obzirom na sudjelovanje u raznim oblicima pedagoške izobrazbe, njihovo stručno usavršavanje općenito i njihovo prethodno formalno pedagoško obrazovanje (Aškerc i Kočar, 2015). Postoje istraživanja o disciplinarnim posebnostima nastave na sveučilišnoj razini, ali vrlo je malo istraživanja provedeno o pedagoškoj izobrazbi sveučilišnih nastavnika iz različitih akademskih disciplina ((Batanero i Carmen, 2007; Kolari i Savander-Ranne, 2002; Pleschova i Simon, 2009). Posebno je uočljiv nedostatak detaljnih istraživanja o vezama između disciplina, pedagoške izobrazbe i usredotočenosti na nastavu umjesto na istraživanje, a kao rezultat toga nema ni dovoljno empirijskih dokaza koji idu u prilog izradi politike pedagoške izobrazbe na nacionalnoj razini - s obzirom na discipline. Stoga, svrha je ovog istraživanja ispitati razlike između sveučilišnih nastavnika iz različitih disciplina s naglaskom na njihovim stavovima prema nastavi na sveučilišnoj razini i pedagoškoj izobrazbi općenito.

\section{Nastava i pedagoška izobrazba u visokom obrazovanju}

Osiguranje kvalitete nastave na sveučilišnoj razini ima ključnu ulogu - ona se održava putem razvoja i provedbe različitih programa izobrazbe ${ }^{1}$, a uključuje i razvoj usklađenih nastavničkih vještina sveučilišnih nastavnika te njihovu procjenu (Mara i Mara, 2011). Knigth, Tait i Yorke (2006) pisali su o tome kako bi programi stručnog usavršavanja također trebali imati utjecaja na sustav kao cjelinu, a ne samo ciljati na promjene kod nastavnika. Stoga nastava na sveučilišnoj razini uključuje individualne strategije za izobrazbu akademskog osoblja, strategije koje uključuju studente, strategije koje uključuju druge sveučilišne nastavnike i strategije koje se pokreću na sveučilišnoj razini (Knight i sur., 2006). Istraživanje o izobrazbi nastavnika na sveučilišnoj razini relativno je novo područje istraživanja (Pleschova i Simon, 2009), a istraživanja u

\footnotetext{
${ }^{1}$ Kod citiranja različitih autora zadržali smo termine koji su se koristili u primarnom izvoru - osim termina pedagoška izobrazba koriste se i neki drugi termini, kao što su: edukacija, pedagoška obuka, programi stručnog usavršavanja, itd. U našem autorskom tekstu uvijek upotrebljavamo termin "pedagoška izobrazba” kada govorimo o različitim oblicima pedagoških programa ili tečajeva za sveučilišne nastavnike.
} 
obrazovnom i pedagoškom usavršavanju još su uvijek malobrojna (Endrizzi, 2011). Stes (2009) je, međutim, primijetio da je stručno usavršavanje u području same nastave za sveučilišne nastavnike postalo jako važna tema.

Pokazalo se da je motivacija nastavnika vrlo važna u nastavničkoj profesiji, jer se intrinzična motivacija povećava kada postoji veća osobna želja za radom u nastavničkoj profesiji (Mara i Mara, 2011). Neki autori prikazuju usavršavanje iskusnih nastavnika s obzirom na lakoću s kojom vode nastavni proces, kao i s obzirom na njihovo znanje i vještine (Åkerlind, 2003). Kada procjenjuju nastavnikovu želju za izobrazbom (Pleschova i Simon, 2009), oni se usredotočuju na različite faktore, kao što su spol, profesionalni planovi, profesionalni status i godine studiranja. Također, pokazuju vezu između pedagoške izobrazbe i nastave na sveučilišnoj razini (Camblin i Steger, 2000; Postareff, Lindblom-Ylänne, i Nevgi, 2007). Iako Postareff i sur. (2007) tvrde da se željeni učinak može postići tek dugoročnim programima izobrazbe i da se nastavnikov pristup nastavnom procesu mijenja sporo. Općenito govoreći, gotovo sva istraživanja koja se bave utjecajem pedagoške izobrazbe pokazala su da je on pozitivan i na nastavni proces sveučilišnih nastavnika, i na nastavnike i studente (Coffey i Gibbs, 2000, Pleschova i Simon, 2009; Postareff i sur. 2007). U istraživanju koje su proveli Gibbs i Coffey (2004) tijekom dužeg vremenskog razdoblja u 22 sveučilišta iz osam država pokazalo se da pedagoška izobrazba može poboljšati različite elemente nastavnog procesa (prema evaluaciji koju su dali studenti). Tako se pokazalo da sveučilišni nastavnici koji pohađaju pedagošku izobrazbu rade bolje od onih koji nisu pohađali takvu izobrazbu (Trowler i Bamber, 2005), a sudjelovanje u pedagoškoj izobrazbi može pomoći nastavnicima kako bi unaprijedili proces učenja kod svojih studenata. U nekim državama (npr. Švedskoj, Australiji i Ujedinjenom Kraljevstvu) razmatra se uvođenje obvezne pedagoške izobrazbe za sveučilišne nastavnike, a u nekim je državama takva politika već uvedena. U Norveškoj svi nastavnici koji imaju zvanje predavača trebaju imati „osnovne pedagoške kompetencije” nakon pohađanja pedagoške edukacije u trajanju od 100 sati (3 do 4 tjedna) (Varnava-Marouchou, 2010).

„Institucije visokog obrazovanja izravno su odgovorne za pedagošku izobrazbu sveučilišnih nastavnika" (Mara i Mara, 2011, str. 1413), a Pleschova i Simon (2009) došli su do zaključka da će se, sve dok u zemljama članicama Europske unije traje postupak osiguranja kvalitete, na institucijama visokog obrazovanja nuditi tečajeve pedagoške izobrazbe. Osim toga, autori (Pleschova i Simon, 2009, str. 246) su predstavili zanimljive rezultate koji pokazuju da „institucije koje su uspješne u istraživanjima također shvaćaju da je još važnije svojim doktorandima pružiti pedagošku naobrazbu /.../ (zato) je prikladnije govoriti o općoj kvaliteti obrazovnih institucija nego grupirati europska sveučilišta u obrazovne i istraživačke institucije." Kako navode Pleschova i Simon (2009), barem dvije trećine ispitanika u njihovu istraživanju voljelo bi usvojiti nastavničke vještine. Međutim, u većini institucija visokog obrazovanja nastava se smatra izoliranom i uvelike nekoordiniranom aktivnošću (Endrizzi, 2011), što bi moglo značiti da je neformalna izobrazba prevladavajući pristup u suvremenoj praksi stručnog usavršavanja (Knight i sur., 2006). Marentič Požarnik i Lavrič $(2015$, str. 79$)$ 
naglašavaju da se „izvrsnost nastavničkih kompetencija” mora (sustavno i službeno) razvijati tijekom nastavnikove karijere, jer te kompetencije sveučilišni nastavnici nemaju „u krvi”. Pedagoške kompetencije mogu se u određenoj mjeri nesustavno i neformalno razvijati učenjem $u$ slobodno vrijeme i učenjem putem vlastitog iskustva, ili pak oponašanjem drugih nastavnika. Međutim, neki autori (Trigwell, Martin, Benjamin i Prosser, 2000) smatraju da formalno organizirano učenje ima puno veću vrijednost jer uključuje akademski pristup poučavanju, slično kao i uobičajeni pristup istraživanju u različitim disciplinama. ,Takav pristup temelji se ne samo na poučavanju nego na poučavanju kao nauci” (Trigwel i sur., 2000, str. 15).

\section{Izobrazba sveučilišnih nastavnika u akademskim disciplinama}

Budući da postoje različite faze nastavničke karijere ili njihova stručnog pedagoškog usavršavanja i kvalifikacija (Kugel, 1993), razumljivo je da postoje različite vrste pedagoške izobrazbe. Aškerc Veniger (2016) navodi četiri različite mogućnosti pedagoške izobrazbe ${ }^{2}$, a Aškerc i Kočar (2015) utvrdili su da postoje statistički značajne razlike u stavovima i sudjelovanju sveučilišnih nastavnika iz različitih disciplina (ISCED skupina) u različitim vrstama pedagoške izobrazbe. Endrizzi (2011) također navodi da se potrebe za edukacijom mijenjaju ovisno o dobi, spolu, starosti i akademskoj disciplini nastavnika. Na početku karijere utjecaj pedagoške edukacije donekle varira ovisno o disciplinama (Stes i sur., 2010). Međutim, duži procesi edukacije rezultiraju pozitivnijim utjecajem na nastavnikovo shvaćanje nastavnog procesa i učenja, a utjecaj izobrazbe (u različitim akademskim disciplinama) uvelike ovisi o duljini procesa edukacije (Postareff i sur., 2007).

Zbog razlika u sudjelovanju u raznim oblicima pedagoške izobrazbe, kao i u stavovima prema njoj s obzirom na akademske discipline, u ovom radu bismo željeli pokazati koliko su značajne razlike među disciplinama kod sudjelovanja u stavovima nastavnika prema pedagoškoj izobrazbi (PI1) te postoji li bilo kakva veza između sudjelovanja u pedagoškoj izobrazbi i stavova prema toj izobrazbi s obzirom na različite discipline (PI2).

Marentič Požarnik (2009) navodi da je količina vremena koje su sudionici trebali kako bi samostalno odradili zadatke zadane u pedagoškoj edukaciji u Sloveniji varirala između 10 i 30 sati, s prosjekom od oko još pola dodatnog vremena potrebnog za samostalno učenje ( 24 sata na 48 ili 78 sati za cijelu izobrazbu). Ne postoje preporuke ni slaganje o tome koliko bi vremena trebalo biti potrebno i ponuđeno za pedagošku izobrazbu sveučilišnim nastavnicima u Sloveniji, posebno u određenim disciplinama. Razlog tome mogla bi biti činjenica da problem pedagoških kvalifikacija i izobrazbe nije jasno definiran u slovenskom zakonu u visokoškolskom obrazovanju (Aškerc, 2014; Aškerc i Kočar, 2015). Dok neki nastavnici pohađaju pedagošku izobrazbu za koju su im potrebna 72 sata kako bi samostalno dovršili zadatke, a u nekim

\footnotetext{
${ }^{2}$ 1) obvezna početna pedagoška izobrazba za sve nastavnike, 2) obvezna početna pedagoška izobrazba za nastavnike bez prethodnog formalnog pedagoškog obrazovanja, 3) obvezna daljnja pedagoška izobrazba za sve nastavnike (svakih nekoliko godina) i 4) daljnja izobrazba samo za one nastavnike čiji su rad studenti slabo ocijenili.
} 
disciplinama i više od toga (npr. tu se ističe zdravstvo), sveučilišnim nastavnicima u Sloveniji se općenito nude (neformalni) tečajevi koji traju kraće vrijeme.

Kako kod sveučilišnih nastavnika iz različitih disciplina postoje razlike i u općoj stopi sudjelovanja u pedagoškoj izobrazbi i u količini vremena provedenog u edukacijama, također bismo željeli saznati i koliko pedagoške izobrazbe ima prosječan sveučilišni nastavnik iz određene akademske discipline (PI3).

\section{Pedagoške kompetencije sveučilišnih nastavnika u akademskim disciplinama}

Pedagoška izobrazba od ključne je važnosti za razvoj pedagoških kompetencija sveučilišnih nastavnika. Pedagoška kompetencija ${ }^{4}$ ne uključuje samo nastavničke vještine i znanost o poučavanju, nego izlazi izvan tih okvira (Olatunji, 2013). Izvrsni sveučilišni nastavnici iznimno dobro poznaju svoje predmetno područje, stvaraju prirodno okruženje za kritičko učenje, smatraju da je nastava jednako važna kao i istraživanje i znanost, mogu zadobiti i zadržati pažnju studenata, tretiraju studente objektivno i sustavno procjenjuju napredak studenata (Bain, 2004). Suciu i Mâță (2011, str. 411-412) smatraju da su „pedagoške kompetencije u tijesnoj vezi s tri važna faktora obrazovanja: obrazovnim postignućem/uspjehom/učinkovitošću, stručnim usavršavanjem i društvenim promjenama." Webler (2013) daje popis ključnih kompetencija za sveučilišne nastavnike koji su ujedno i refleksivni praktičari: samokompetencija, društvena kompetencija (uključuje opće društvene kompetencije i posebne društvene kompetencije nastavnika) i stručna kompetencija u vlastitoj akademskoj disciplini ili predmetnom području. Endrizzi (2011, str. 1) ukratko sažima stavove Rege Coleta i Berthiaumea (2009) koji smatraju da je „identitet profesije također ponajprije pitanje pripadnosti određenoj disciplini”, kako su akademski građani prvo istraživači, a onda nastavnici.

Stoecker (1993) citira Adamsa (1976), koji je napisao da je utjecaj jedinstvenih disciplinarnih stavova, uvjerenja i ponašanja tako očit kod nekih da su ga opisali kao sveučilišno akademsko pleme. Metafora akademska „plemena i teritoriji” (Becher i Trowler, 2011) jako je važna u tom kontekstu u vezi s nastavnim procesom i procesom učenja, a pogotovo u vezi s razvojem akademskog osoblja i akademskih disciplina u različitim disciplinarnim kulturama, a autori daju naznaku koja je disciplina smještena u kojem području ${ }^{5}$. Slično tome, tri dimenzije Biglanove (1973) klasifikacije uključuju tvrdo-meku dimenziju, čistu-primijenjenu dimenziju i živu-neživu dimenziju, u kojoj usporedba živih i neživih disciplina upućuje na to da su znanstvenici iz područja živih disciplina više društveno aktivni, no manje zainteresirani za nastavni proces i u njegu uključeni, nego oni koji pripadaju području neživih disciplina. Smart i Elton (1982 u Stoecker, 1993) također su zaključili da fakulteti koji se bave neživim

\footnotetext{
${ }^{3} \mathrm{U}$ empirijskom dijelu istraživanja definirani su skupovi pedagoških kompetencija u skladu sa studentskim evaluacijskim upitnikom, koji je bio važeći u slovenskim institucijama visokog obrazovanja u vrijeme kada su se podatci prikupljali.

${ }^{4}$ Tvrdo-čisto područje (prirodne znanosti), meko-čisto područje (humanističke i čiste društvene znanosti), tvrdoprimijenjeno područje (tehnologije) i meko-primijenjeno područje (primijenjene društvene znanosti).
} 
disciplinama pokazuju veći interes i odvajaju više vremena za nastavne aktivnosti. Neumann, Parry i Becher (2002) opisali su razlike u strukturi znanja nastavnika i općim nastavnim metodama s obzirom na nastavnikovu pripadnost tvrdim, čistim, mekim i primijenjenim znanostima ${ }^{5}$. Postoje neke opće razlike između disciplina $s$ obzirom na učenje i poučavanje. Nastavnici iz područja mekih znanosti općenito troše više vremena na pripremu nastave, a njihovo je određivanje sadržaja znanja neodređenije u usporedbi s tvrdim znanostima. Nevgi, Postareff i Lindblom-Ylänne (2004, str. 12) također su došli do zaključka da „način prenošenja informacije/pristup nastavi koji je usredotočen na nastavnika i konceptualna promjena/pristup nastavi koji se usredotočuju na studenta značajno variraju u različitim disciplinama."

Iako postoje razlike u pristupu nastavnom procesu, vrstama nastavnih metoda i prijenosu znanja koji su rezultat razlika u disciplinama, u našem bismo istraživanju željeli ispitati detaljnije kako nastavnici iz različitih disciplina shvaćaju važnost nastave na sveučilišnoj razini i kako samoprocjenjuju kvalitetu vlastitog nastavnog procesa (PI4). Općenito gledajući, može se reći da shvaćanje, zahtjevi i očekivanja od nastavnog procesa i pedagoške kompetencije variraju ovisno o različitim akademskim disciplinama. Međutim, možemo također tvrditi da ne postoje opći sustavni pristupi pedagoškoj izobrazbi u pojedinim disciplinama, što ovisi i o posebnostima određenog područja i njegovoj didaktici. U pripremanju buduće generacije profesora političkih znanosti, Pleschova i Simon (2009) došli su do zaključka da su svi doktorandi koji su završili nastavnički smjer smatrali da su im pedagoška znanja korisna. Štoviše, Batenero i Carmen (2007) došli su do zaključka da je početna pedagoška izobrazba budućih statističara vrlo korisna, no smatrali su da je 60 sati nastave nedovoljno kako bi se usvojilo osnovno didaktičko znanje. Slično statističkoj disciplini, mnogi mladi ljudi danas ne smatraju da su strojarstvo ili znanstveni predmeti/discipline jako privlačni. Stoga, „sposobnost da se pojedinac uhvati u koštac s novim teorijama učenja i ovlada novim nastavnim metodama može predstavljati rješenje za postizanje boljih rezultata učenja i za bolju motivaciju" (Kolari i Savander-Ranne, 2002, str. 59). Nastavnici iz područja medicine također navode pozitivne aspekte pedagoške izobrazbe, a Costa (2010) tvrdi da su potrebu za promjenama u nastavnoj praksi u području zdravstva prepoznali mnogi drugi autori, uključujući potrebu za edukacijom refleksivnih nastavnika u području zdravstva. Glavna prednost, koju je navelo $71 \%$ ispitanika, bila je mogućnost da se dođe do novih spoznaja o nastavnim metodama, tj. nastavnim tehnikama/metodama, procesu učenja i poučavanja, komunikaciji, procjeni procesa učenja i odnosu nastavnik-student.

Pedagoška izobrazba općenito je prepoznata kao korisna u većini disciplina, ako ne i u svima. Međutim, čini se da svaka disciplina ima svoje specifičnosti s obzirom na potrebu za pedagoškom izobrazbom i s obzirom na važnost nastavne prakse. Stoga je svrha

\footnotetext{
${ }^{5}$ Matematika, fizika i kemija primjeri su čistih tvrdih znanost; povijest, umjetnost i estetika čiste su meke znanosti; medicina i strojarstvo primjeri su primijenjenih tvrdih znanosti, a primjeri su primijenjenih mekih znanosti pravo ili teologija (Neumann i sur., 2002).
} 
ovog istraživanja također bila i doći do zaključka o najvažnijim razlikama u stavovima prema pedagoškoj izobrazbi i nastavi na sveučilišnoj razini kod nastavnika iz različitih akademskih disciplina, tj. doći do zaključka o tome što ih najviše razdvaja (PI5).

\section{Metode}

Cilj je ovoga rada ispitati utjecaj različitih akademskih disciplina sveučilišnih nastavnika na različite aspekte nastavnog procesa, pedagošku izobrabzu i nastavu na sveučilišnoj razini općenito, što je već spomenuto prije u teorijskom dijelu ovoga rada, putem postojećih istraživanja i zaključaka u tom području. Prije pregleda dizajna i rezultata istraživanja opisat će se kontekst istraživanja.

Istraživanje je provedeno 2013. godine s pomoću online upitnika kao metode prikupljanja podataka, a pokrilo je teme povezane sa slovenskim pedagoškim okruženjem u visokom obrazovanju, a koje su uglavnom uključivale dimenzije ponašanja, stavova i percepcija o pedagoškoj izobrazbi i nastavi na sveučilišnoj razini. Alat za prikupljanje podataka bio je dizajniran, programiran na internetu, a kasnije ažuriran, nakon što su odgovori 24 sudionika u pilot-istraživanju definirali populaciju. Poveznica na finalnu inačicu ankete e-poštom poslana je članovima ciljne skupine.

\section{Populacija i uzorak}

Populacija se sastojala od sveučilišnih nastavnika zaposlenih na institucijama visokog obrazovanja u Sloveniji (Sveučilište u Ljubljani, Sveučilište u Mariboru, Sveučilište u Primorskoj, Sveučilište u Novoj Gorici i manje samostalne institucije visokog obrazovanja). Populacija je podijeljena u sljedeće skupine: redoviti profesori, izvanredni profesori, docenti, viši predavači, predavači, lektori (nastavnici jezika), asistenti i instruktori/nositelji predmeta. Prema definiciji, 8.763 zaposlenika činila su populaciju za ovo istraživanje (Statistički ured Republike Slovenije, 2013). Cilj je bio izbjeći uzorkovanje pokušavajući pokriti što veći dio populacije. Stoga je veći dio populacije bio pozvan na sudjelovanje $\mathrm{u}$ istraživanju $(\mathrm{N}=5.650)$, a 513 ispitanika uspješno je popunilo anketu, što odgovara stopi odaziva od 9,1 \% i stopi izbora jedinica u uzorak od 5,9\%. Uzorak se sastojao od jedinica iz različitih područja obrazovanja prema ISCED-u iz 1997. godine (dvoznamenkasta razina), koje su poslije klasificirane $\mathrm{u}$ šest različitih jednoznamenkastih grupa ili disciplina prema ISCED-u: obrazovanje, humanističke znanosti i umjetnost, društvene znanosti, prirodne znanosti, strojarstvo, proizvodnja i graditeljstvo, zdravstvo i socijalna skrb ${ }^{6}$.

\footnotetext{
${ }^{6} \mathrm{U}$ istraživanju 9 skupina Međunarodne standardne klasifikacije obrazovanja - ISCED 1997, a koja se inače sastoji od 25 područja obrazovanja (UNESCO 2012), spojeno je u šest skupina ili disciplina. Dodani su i postotci za ispitanike: 1) obrazovanje - 10,7 \% (14 nastavničke i obrazovne znanosti); 2) humanističke znanosti i umjetnost - 15,6 \% (21 umjetnost, 22 humanističke znanosti; 3 ) društvene znanosti - 26,1 \% (31 društvene i biheviorističke znanosti, 32 novinarstvo i informatologija, 34 poslovanje i poslovna administracija, 38 pravo, 81 osobne usluge, 84 usluge prijevoza, 86 zaštitarske usluge); 4) prirodne znanosti - 19,3 \% (42 biološke znanosti, 44 fizika, 46 matematika i statistika, 48 računalstvo, 6 poljoprivreda, 62 poljoprivreda, šumarstvo i ribarstvo, 64 veterina, 85 zaštita okoliša); 5) strojarstvo, proizvodnja i graditeljstvo - 18,3\% (52 strojarstvo, 54 proizvodnja i obrada, 58 arhitektura i gradnja) i 6) zdravstvo i socijalna skrb - 9,9 \% (72 zdravstvo, 76 socijalna skrb).
} 
Naglašavamo važnost dodatnog opreza pri interpretaciji i upotrebi podataka istraživanja koji su dobiveni niskom stopom odaziva. Međutim, neki su istraživači zaključili da podatci dobiveni niskom stopom odaziva još uvijek mogu pokazati točna mjerenja (Horta, 2013), a drugi su došli do spoznaja da visoka stopa odaziva nije uvijek pokazatelj veće točnosti rezultata (Yeager, Krosnick, Chang, Javitz, Levendusky, Simpser, i Wang, 2011). Osim toga, procijenjeno je da je stopa odaziva u online istraživanjima prosječno $11 \%$ niža od one koja se navodi u istraživanjima koja se koriste tradicionalnim metodama prikupljanja podataka (Lozar Manfreda, Bosnjak, Berzelak, Haas, i Vehovar, 2008). Nije nevažan podatak da je naše istraživanje provedeno na uzorku visokoobrazovane i specijalizirane populacije, koja općenito ima malo slobodnog vremena. $U$ tom kontekstu smatramo da podatci koje smo u istraživanju dobili još uvijek prikazuju zanimljiv i koristan pregled stvarne situacije u Sloveniji.

\section{Opterećenje podataka}

$\mathrm{Na}$ temelju rezultata analize demografske strukture, zbog stope neodaziva i zbog stope podobuhvata, poslije smo uočili potrebu opterećenja podataka titulom nastavnika kako bismo napravili neophodne prilagodbe i bolje prikazali populaciju. Uspoređujući distribuciju populacije i distribuciju uzorka u varijabli nastavnikova titula, uočili smo da su instruktori i asistenti u značajnoj mjeri nedovoljno zastupljeni, a da su viši lektori i docenti u značajnoj mjeri previše zastupljeni. Kako smo primijetili neke važne razlike među nastavnicima s različitim titulama u njihovim stavovima i sudjelovanju, krajnji rezultati naših analiza mogli su biti neobjektivni, pa je zato bilo potrebno uvesti faktor opterećenja. Varijabla je izračunata iz poznate distribucije populacije (vidi Statistički ured Republike Slovenije, 2013) i analizirane distribucije uzorka.

\section{Statističke metode}

Podatci su izračunati s pomoću SPSS 22.0 statističkog programa. Prikazali smo deskriptivnu statistiku, poput frekvencije, prosjeka i mjerenja varijabilnosti. Kako bismo prikazali razlike među disciplinama, primijenili smo hi-kvadrat test i t-test neovisnog uzorka, proveli analizu varijance i dodali mjerenja veličine učinka gdje je to bilo potrebno: Cohenov d za veličinu učinka dviju uspoređivanih grupa i eta kvadrat za veličinu učinka za više od dvije uspoređivane skupine. Koristili smo se statističkim metodama za smanjenje dimenzije/izradu indeksa (faktorska analiza - maksimalna vjerojatnost $s$ Varimax rotacijom), analizu pouzdanosti za novoizrađene indekse (Cronbachova alfa) i za stvaranje linearnih kombinacija obilježja koja su najviše karakterizirala ili razdvajala naše analizirane discipline (diskriminativna analiza).

\section{Rezultati}

Prvo predstavljamo razlike u stavovima prema različitim vrstama pedagoške izobrazbe kod nastavnika iz različitih disciplina i u njihovu sudjelovanju u pedagoškoj izobrazbi (PI1). Radarska tablica (Slika 1) daje vizualni prikaz rezultata, naglašavajući 
razlike između nastavnika iz različitih disciplina. Na lijevoj strani tablice prikazane su usporedbe sudjelovanja sveučilišnih nastavnika iz različitih disciplina u pedagoškoj izobrazbi, a ostatak tablice prikazuje njihove stavove, tj. koliko važnom smatraju pedagošku izobrazbu (za različite svrhe). Izračunati su postotci za one koji su izrazili slaganje (4) ili potpuno slaganje (5) na skali od 5 stupnjeva s izjavama o važnosti različitih vrsta pedagoške izobrazbe.

Može se vidjeti da postoje neke značajne razlike kada se radi o sudjelovanju sveučilišnih nastavnika iz različitih disciplina u pedagoškoj izobrazbi. Nastavnici iz discipline zdravstvo i socijalna skrb najviše su sudjelovali u pedagoškoj izobrazbi sveučilišnih nastavnika, a zatim slijede nastavnici iz područja društvenih znanosti. S druge pak strane, nastavnici iz područja prirodnih znanosti i oni iz područja strojarstva, proizvodnje, graditeljstva i obrazovanja uložili su jako malo vremena u pedagošku izobrazbu u razdoblju od 10 godina prije provedbe istraživanja.

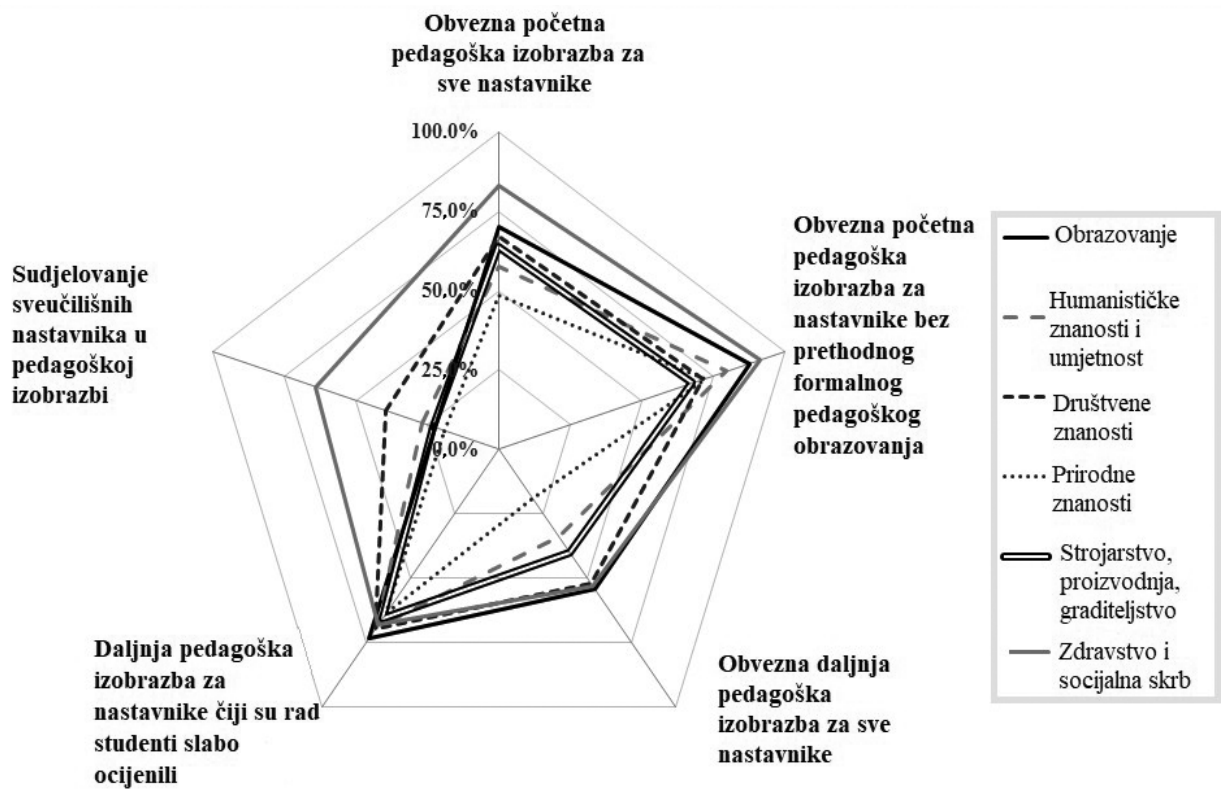

Prikaz 1. Razlike u sudjelovanju u i stavovima prema pedagoškoj izobrazbi

Uspoređujući mišljenja nastavnika iz različitih akademskih disciplina o različitim vrstama pedagoške izobrazbe, uočili smo značajne razlike (hi-kvadrat test, $\mathrm{p}$ vrijednost $<0,05)$, osim kod daljnje pedagoške izobrazbe sveučilišnih nastavnika čiji su rad studenti slabo ocijenili ( $p$ vrijednost $>0,05$ ). Zdravstvo i socijalna skrb skupina je $u$ kojoj se, općenito govoreći, pedagoška izobrazba najviše potiče, pogotovo obvezna početna pedagoška izobrazba za sve sveučilišne nastavnike i one koji nemaju prethodno formalno pedagoško obrazovanje. Iza nastavnika iz te discipline slijede nastavnici iz 
područja obrazovanja, koji su pokazali najveću potporu za daljnju pedagošku izobrazbu nastavnika čiji su rad studenti slabo ocijenili. Od svih disciplina nastavnici iz područja humanističkih znanosti i umjetnosti te prirodnih znanosti ističu se kao nastavnici koji su pokazali relativno slabu potporu pedagoškoj izobrazbi, naročito kada se radi o obveznoj pedagoškoj izobrazbi za sve sveučilišne nastavnike, uključujući i početne i daljnje oblike takve izobrazbe. Nastavnici prirodnih znanosti, kao i oni iz područja strojarstva, proizvodnje i graditeljstva također se ističu kao skupina nastavnika s najnižim postotkom sudjelovanja u pedagoškoj izobrazbi $(<25 \%)$.

Stoga smo željeli procijeniti koliko je vremena prosječni sveučilišni nastavnik iz određene akademske discipline proveo u pedagoškoj izobrazbi prema broju sati (PI3), uzimajući u obzir i razlike u sudjelovanju i prosječno vrijeme trajanja određene edukacije iz područja pedagogije. Zato su u analizu bili uključeni svi ispitanici, pa čak i oni koji nikada nisu sudjelovali u bilo kakvim oblicima pedagoške izobrazbe.

\section{Tablica 1}

Tablica 1 prikazuje rezultate o broju sati provedenih u pedagoškoj izobrazbi prema akademskoj disciplini nastavnika. Dvije se discipline pozitivno ističu - društvene znanosti i zdravstvo i socijalna skrb sa 17,12 sati i 16,17 sati, za svaku pojedinačno. Prosječan broj sati provedenih pohađajući edukacije najniži je u disciplinama prirodne znanosti i strojarstvo, proizvodnja i graditeljstvo (manje od 8 sati za svaku). Uključivanjem u analizu svih nastavnika/ispitanika (i onih koji sudjeluju i onih koji ne sudjeluju u pedagoškoj izobrazbi) iz uzorka, razlike među disciplinama jasnije su prikazane i označene, što nam također omogućava da pretpostavimo da je pedagoška izobrazba relativno nepopularna u nekim disciplinama.

Nadalje, pokušali smo odrediti kako slovenski nastavnici iz različitih disciplina shvaćaju važnost nastave na sveučilišnoj razini i kako samoprocjenjuju kvalitetu vlastitog nastavnog procesa (PI4). Uz rezultate o stavovima prema pojedinim oblicima pedagoške izobrazbe (Prikaz 1), također smo pokušali sažeti kako nastavnici iz različitih disciplina općenitoo shvaćaju važnost pedagoške izobrazbe (PI1). Najprije smo proveli faktorsku analizu (maksimalna vjerojatnost) s 15 varijabli, povezanih ili sa stavovima prema pedagoškoj izobrazbi ili sa stavovima nastavnika prema njihovu vlastitom nastavnom procesu. Analiza je provedena da bi se smanjio broj osobnih i perceptivnih dimenzija. Kako je broj varijabli u upitniku koji se koristio za mjerenje stavova prema pedagoškoj izobrazbi i vlastitoj nastavi bio prilično velik, uveli smo indekse kao konstrukte pokazatelja za daljnju komparativnu analizu. Kaiser-MeyerOlkin (KMO) mjera adekvatnosti uzorka bila je 0,767 , što se smatra prihvatljivim (Kaiser i Rice, 1974). Tablica 2 prikazuje rotirano rješenje (Varimax rotacija) s četiri ekstrahirana faktora (uvjet: svojstvena vrijednost $>1$ ) i varijablama pod opterećenjem (uvjet: $>0,4$ ), što pokazuje i kako su varijable opterećene za svaki faktor i korelaciju između varijabli i faktora. 
Tablica 2

Matrica rotiranih faktora (maksimalna vjerojatnost i Varimax s Kaiserovom normalizacijom

\begin{tabular}{|c|c|c|c|c|}
\hline & \multicolumn{4}{|c|}{ Faktor } \\
\hline & 1 & 2 & 3 & 4 \\
\hline $\begin{array}{l}\text { Q11.1 Obvezna početna pedagoška izobrazba za sve } \\
\text { nastavnike }\end{array}$ & 805 & & & \\
\hline $\begin{array}{l}\text { Q11.2 Obvezna početna pedagoška izobrazba za } \\
\text { nastavnike bez prethodnog formalnog pedagoškog } \\
\text { obrazovanja }\end{array}$ & 684 & & & \\
\hline $\begin{array}{l}\text { Q11.3 Obvezna daljnja pedagoška izobrazba za sve } \\
\text { nastavnike }\end{array}$ & ,719 & & & \\
\hline $\begin{array}{l}\text { Q11.4 Daljnja izobrazba samo za one nastavnike čiji su } \\
\text { rad studenti slabo ocijenili }\end{array}$ & 428 & & & ,678 \\
\hline $\begin{array}{l}\text { Q11.5 Studentske evaluacije kao dobra mjera } \\
\text { kvalitete nastave }\end{array}$ & & & &, 513 \\
\hline $\begin{array}{l}\text { Q11.6 Potvrda o pedagoškoj izobrazbi kao sastavnom } \\
\text { dijelu habilitacije }\end{array}$ & ,720 & & & \\
\hline $\begin{array}{l}\text { Q11.7 Nastavnikovo zadovoljstvo načinom stjecanja } \\
\text { pedagoške kompetencije }\end{array}$ & & & & \\
\hline Q12.1 Važnost dana kvaliteti predavanja/seminara* & & & ,725 & \\
\hline $\begin{array}{l}\text { Q12.2 Važnost dana upotrebi aktivnih oblika i metoda } \\
\text { rada* }\end{array}$ & & & 633 & \\
\hline $\begin{array}{l}\text { Q12.3 Važnost dana objektivnom ocjenjivanju/ } \\
\text { evaluaciji rada studenata* }\end{array}$ & & &, 530 & \\
\hline $\begin{array}{l}\text { Q12.4 Važnost stavova, dostupnost nastavnika/ } \\
\text { suradnika za razgovor i pomoć studentima* }\end{array}$ & & &, 578 & \\
\hline Q13.1 "Moja predavanja su jako kvalitetna"** & & ,843 & & \\
\hline $\begin{array}{l}\text { Q13.2 "Koristim se aktivnim oblicima i metodama } \\
\text { rada"*** }\end{array}$ & & ,680 & & \\
\hline $\begin{array}{l}\text { Q13.3 "Moja evaluacija/ocjenjivanje rada studenata je } \\
\text { jako kvalitetno"** }\end{array}$ & & 741 & & \\
\hline $\begin{array}{l}\text { Q13.4 "Moja sposobnost razgovora sa studentima i } \\
\text { pomaganja studentima, kao i moj odnos s njima, vrlo } \\
\text { su kvalitetni"*** }\end{array}$ & & ,608 & & \\
\hline Svojstvena vrijednost & 3,523 & 2,921 & 1,590 & 1,244 \\
\hline$\%$ varijance & 23,49 & 19,47 & 10,60 & 8,30 \\
\hline
\end{tabular}

*... kao jedna od pedagoških kompetencija sveučilišnih nastavnika.

*.... percepcije nastavnika o kvaliteti vlastitoga nastavnog rada (u najširem smislu).

Skale: Likertova skala s 5 stupnjeva ( 1 - Uopće se ne slažem, 5 - Potpuno se slažem) za varijable u dijelu Q11; Likertova skala sa 7 stupnjeva (1 - Uopće nije važno, 7 - Iznimno je važno) za varijable u dijelovima Q12 i Q13.

Na temelju rezultata faktorske analize sastavili smo četiri različita indeksa kao zbroj pokazatelja/varijabli. Kako je opterećenje pokazatelja Daljnja izobrazba samo za one nastavnike čiji su rad studenti slabo ocijenili veće za faktor 4 nego za faktor 1, iskoristili smo ga za stvaranje četvrtog indeksa. Proveli smo analizu pouzdanosti za svaki predloženi indeks te su izrađeni sljedeći indeksi koji će se koristiti u daljnjoj analizi:

1. Važnost pedagoške izobrazbe (varijable faktora 1, Cronbachova alfa 0,829 )

2. Percipirana kvaliteta vlastitog nastavnog procesa (varijable faktora 2, Cronbachova alfa 0,816 ) 
3. Važnost kvalitete poučavanja općenito (varijable faktora 3, Cronbachova alfa $0,709)$

4. Važnost daljnje pedagoške izobrazbe zbog slabog ocjene rada koju su dali studenti (varijable faktora 4, Cronbachova alfa 0,545).

Analiza pouzdanosti pokazala je, kako su vrijednosti Cronbachove alfe za prva tri indeksa bile više od 0,7 , da bi se one mogli koristiti u daljnjim analizama kao vrlo pouzdane mjere. Vrijednost Cronbachove alfe za četvrti indeks bila je nešto niža, ali još uvijek oko 0,6 , što znači da se pouzdanost instrumenta može smatrati jedva prihvatljivom (Ferligoj i sur., 1995). Nakon toga smo proveli analizu varijance (ANOVA) sa sva četiri indeksa kako bismo pregledali razlike u stavovima prema pedagoškoj izobrazbi i vlastitom nastavnom procesu kod nastavnika iz šest različitih disciplina. Testirali smo normalnost i homogenost varijabli, a u slučaju da se nisu mogle dobiti jednake varijance, koristili smo se odgovarajućim post-hoc testom (Dunnettov C).

Rezultati su pokazali da, općenito govoreći, nastavnici smatraju da je pedagoška izobrazba važna u manjoj mjeri (ukupna srednja vrijednost $=3,51$ na skali od 5 stupnjeva). Međutim, postoje neke razlike u važnosti s obzirom na oblike pedagoške izobrazbe među skupinama: nastavnici iz područja prirodnih znanosti ističu se po tome što smatraju da je pedagoška izobrazba manje važna (srednja vrijednost $=3,19$ ), a nastavnici iz područja zdravstva i socijalne skrbi smatraju da je ona nešto važnija (srednja vrijednost $=3,87$ ). Rezultati su vrlo slični rezultatima prikazanima na Slici 1 . Veličina učinka kao kvantitativne mjere jačine razlika izmjerena je s pomoću $\eta^{2}$ (eta kvadrata), s vrijednošću od 0,060, što znači da je veličina učinka osrednja (Cohen, 1988).

U prosjeku, nastavnici smatraju da je kvaliteta njihove nastave (u najširem smislu) dosta visoka (ukupna srednja vrijednost $=5,63$ na ljestvici od 7 stupnjeva). I ovdje postoje neke statistički značajne razlike među skupinama s obzirom na percipiranu kvalitetu vlastite nastave. Statistika veličine učinka $\eta^{2}$ iznosi 0,049 , što znači da je i u ovom slučaju veličina učinka osrednja (Cohen, 1988). Nastavnici iz područja prirodnih znanosti i ovdje se ističu, jer smatraju da je kvaliteta njihove nastave nešto niža. $S$ druge strane, nastavnici iz discipline društvene znanosti i obrazovanje imaju bolje mišljenje o vlastitoj kvaliteti poučavanja.

Na kraju, rezultati su pokazali da otprilike svi nastavnici iz različitih disciplina smatraju da je kvaliteta nastave vrlo bitna (srednje vrijednosti između 6,03 i 6,29 na skali od 7 stupnjeva). Mogu postojati neke razlike među disciplinama s obzirom na važnost kvalitete nastave ( $\mathrm{p}$ vrijednost $<0,5$, dobivena s pomoću ANOVA testa), no post-hoc test je pokazao da ne postoje značajne razlike među skupinama. Osim toga, rezultati pokazuju da ne postoje statistički značajne razlike među nastavnicima iz različitih disciplina u važnosti daljnje pedagoške izobrazbe nastavnika čiji su rad studenti slabo ocijenili. 
Rezultati su pokazali značajne razlike u navedenoj važnosti pedagoške izobrazbe kod nastavnika iz različitih disciplina. Zato smo željeli detaljnije analizirati podatke kako bismo ustanovili postoje li bilo kakve veze između sudjelovanja u pedagoškoj izobrazbi (PI2) općenito, kao i u različitim akademskim disciplinama, kao i stavova prema njima.

\section{Prikaz 2}

Rezultati prikazani na prikazu 2 pokazuju da, općenito govoreći, postoje statistički značajne razlike $u$ stavovima prema pedagoškoj izobrazbi među nastavnicima koji su pohađali takvu izobrazbu i onima koji nisu. Veličina učinka, kao kvantitativna mjera jačine razlike, izmjerena je s pomoću Cohenove d vrijednosti, a vrijednost za sve nastavnike iz svih disciplina iznosila je 0,63 , što znači da je veličina učinka bila srednja (Cohen, 1962). To znači da oni nastavnici koji su osobno sudjelovali u pedagoškoj izobrazbi u većoj mjeri smatraju da je takva izobrazba važna. Razlike među nastavnicima koji su u njoj sudjelovali i onima koji nisu, prema disciplinama kojima pripadaju, nisu statistički značajne u većini slučajeva, što bi se također moglo pripisati manjoj veličini disciplinarnih poduzoraka. Discipline u kojima su uočene razlike koje nisu statistički značajne na razini $\alpha=0,05$, bile su obrazovanje i zdravstvo i socijalna skrb. S druge pak strane, discipline sa statistički značajnim razlikama na razini $\alpha=0,05$, ali ne i na razini $\alpha=0,01$, humanističke su znanosti i umjetnost, strojarstvo, proizvodnja i graditeljstvo. Jedine dvije discipline sa značajnim razlikama (na razini $\alpha=0,01) \mathrm{su}$, dakle, društvene znanosti i prirodne znanosti. Veličina učinka, izmjerena s pomoću Cohenova d, bila je 0,70 i 0,56 za svaku posebno, što znači da su veličine učinka između srednjih i velikih (Cohen, 1962).

Kako bismo proširili i generalizirali rezultate, željeli smo zaključiti svoje istraživanje naglašavanjem najvažnijih razlika u stavovima nastavnika iz različitih disciplina prema pedagoškoj izobrazbi i kvaliteti vlastite nastave (PI5). U prethodnom odlomku smo naveli da su nastavnici iz područja prirodnih znanosti i strojarstva, proizvodnje i graditeljstva, tradicionalno tvrdih znanosti, manje uključeni u pedagošku izobrazbu i da imaju nešto malo drugačije stavove prema nastavi i takvoj vrsti edukacije. $S$ druge strane, čini se da su nastavnici iz područja zdravstva i socijalne skrbi (a velika većina njih radi u polju zdravstva) sličniji nastavnicima mekih nego nastavnicima tvrdih znanosti. Koristeći se tim rezultatima, klasificirali smo discipline (iz originalne dvoznamenkaste varijable ISCED-a iz 2011. godine) u: 1) meke znanosti (čiste i primijenjene), 2) tvrde znanosti (čiste i primijenjene, ne uključujući poddisciplinu zdravstvo) i 3) zdravstvo, na temelju revidiranog Biglanova modela klasifikacije (Stoecker, 1993). Proveli smo diskriminativnu analizu kako bismo istaknuli najznačajnije razlike između skupina disciplina, pokušavajući pronaći linearnu kombinaciju obilježja koja najbolje karakterizira ili najviše dijeli skupine te da bismo vizualno prikazali rezultate.

Tablica 3 
Tablica 3 prikazuje i standardizirane koeficijente i strukturne koeficijente za najznačajnije diskriminativne funkcije, kao što su njihove svojstvene vrijednosti, postotak objašnjene varijance, kanoničke korelacije i statistiku hi-kvadrata sa značajnošću diskriminativnih funkcija. Potrebno je napomenuti da su svojstvene vrijednosti prilično niske $(0,107$ i 0,007$)$, što znači da su razlike među sveučilišnim nastavnicima iz različitih disciplina male. Štoviše, što se tiče postotka varijance, koji je izračunat kao omjer svojstvene vrijednosti funkcije i zbroja svih svojstvenih vrijednosti, prva funkcija objašnjava većinu varijance $(93,6 \%$ ) našeg diskriminativnog modela, a druga funkcija objašnjava samo $6,4 \%$ varijance modela. Prva bi se funkcija zato trebala, također zbog niske svojstvene vrijednosti i velikog značaja druge diskriminativne funkcije ( $\mathrm{p}$ vrijednost $>0,05$, koja provjerava je li kanonička korelacija dane funkcije jednaka nuli), smatrati jedinom koja razdvaja skupine. Funkcija ima najviše vrijednosti koeficijenta za Važnost pedagoške izobrazbe i Percipiranu kvalitetu vlastite nastave. Stoga je možemo nazvati jednostavno Važnost pedagoške izobrazbe i kvaliteta vlastite nastave.

\section{Prikaz 3}

Slika 3 pokazuje vrijednosti funkcija 1 i 2 za sve jedinice, kao i za grupne centroide (prosjeci neovisnih vrijednosti dijelova skupine koji pokazuju kako su skupine razdvojene). Možemo zaključiti da ne postoji jasna distribucija, jer smo mogli pronaći pojedinačne cjeline, članove različitih skupina/disciplina, raspodijeljenih po prikazanoj tablici, iako su kod većine jedinica iz područja zdravstva vrijednosti funkcije 1 veće od nule. Još uvijek postoje neke statistički značajne razlike, kako pokazuju centroidi za skupine. Kako je već spomenuto, jedina funkcija koja jasno razdvaja skupine je Funkcija 1 koja je nazvana Važnost pedagoške izobrazbe i kvaliteta vlastite nastave. Discipline s najnižim vrijednostima centroida za Funkciju 1 su tvrde znanosti (prirodne znanosti i strojarstvo, proizvodnja i graditeljstvo), a disciplina s najvišom vrijednošću centroida za Funkciju 1 je zdravstvo (kao poddisciplina zdravstva i socijalne skrbi iz domene tvrdih znanosti). Centroid za meke znanosti (obrazovanje, humanističke znanosti i umjetnost i društvene znanosti) nalazi se između, ali je ipak nešto bliži centroidu za zdravstvo nego centroidu za tvrde znanosti, što se tiče vrijednosti Funkcije 1. Stoga možemo zaključiti da meke znanosti (kao i zdravstvo) imaju bolji stav prema pedagoškoj izobrazbi i smatraju da je kvaliteta njihova nastavnog rada veća. Ali trebali bismo naglasiti da iako su razlike statistički značajne, ipak su prilično male, a izvedene diskriminativne funkcije relativno su slabi prediktori pripadnosti skupini.

\section{Rasprava}

Stručno usavršavanje akademika kao sveučilišnih nastavnika postalo je važna tema u politici visokog obrazovanja, u skladu s najnovijim dokumentima u Bolonjskom procesu (Europski standardi i smjernice, 2015; Yerevan communique, 2015; itd.). Međutim, specifična istraživanja o pedagoškom usavršavanju sveučilišnih nastavnika 
i dalje su malobrojna, posebno kada se uzmu u obzir akademske discipline i njihov utjecaj na nastavničke percepcije različitih komponenti nastave na sveučilišnoj razini i stručno usavršavanje samih sveučilišnih nastavnika. U tom kontekstu, u ovom smo istraživanju saznali da postoje značajne razlike među slovenskim nastavnicima iz različitih akademskih disciplina u stavovima prema pedagoškoj izobrazbi i njihovoj percepciji kvalitete nastave na sveučilišnoj razini.

Možemo zaključiti da se discipline najviše razlikuju u bihevioralnoj dimenziji. Općenito govoreći, nastavnici iz disciplina društvene znanosti i zdravstvo i socijalna skrb uglavnom su više uključeni u pedagošku izobrazbu nego nastavnici iz nekih drugih disciplina, sudeći po dobivenom prosječnom broju sati koje nastavnik iz određene discipline provede $u$ različitim oblicima pedagoške edukacije. Nastavnici tradicionalno tvrdih znanosti, kao što su prirodne znanosti i strojarstvo, proizvodnja i graditeljstvo su, s druge strane, znatno manje uključeni u pedagošku izobrazbu. Također, nijedan nastavnik iz bilo koje discipline nije potrošio u prosjeku više od 17 sati na pedagošku izobrazbu u posljednjih deset godina. Kako su istaknuli Stes i suradnici (2010), utjecaj edukacije nastavnika malo varira među disciplinama na početku karijere, a duži proces pedagoške edukacije ima pozitivniji utjecaj (Postareff i sur., 2007). Kako su oni saznali, programi koji duže traju (1 godinu ili programi koji nose barem 30 ECTS bodova) pružaju više mogućnosti i veći utjecaj na pedagoško razmišljanje nastavnika i predodžbe o učenju i poučavanju. S druge strane, kraći tečajevi kod nastavnika mogu izazvati nesigurnost u nastavničke vještine. $U$ našem istraživanju to drugo bi moglo biti povezano s rezultatima u dimenziji koja se tiče stavova ispitanika prema pedagoškoj izobrazbi, o kojima će biti riječi u sljedećem odlomku (Postareff i sur., 2007).

Nastavnici iz različitih disciplina razlikuju se u dimenziji koja obuhvaća stavove, jer uglavnom nastavnici mekih znanosti (posebno iz područja obrazovanja) i zdravstva i socijalne skrbi podržavaju obveznu pedagošku izobrazbu (i to za sve nastavnike) više nego je to slučaj kod nastavnika tvrdih znanosti, uglavnom prirodnih znanosti. Otkrili smo vezu između spomenutih dimenzija, uglavnom između stavova prema različitim vrstama pedagoške izobrazbe u pojedinim disciplinama i za pojedine vrste edukacije. Oni koji su sudjelovali u edukacijama (iako s prosječno malim brojem sati) uglavnom imaju bolji stav prema obveznoj početnoj pedagoškoj izobrazbi u gotovo svim disciplinama. Međutim, sudjelovanje u pedagoškoj izobrazbi uopće ne utječe na stavove sveučilišnih nastavnika iz disciplina obrazovanje i zdravstvo i socijalna skrb. Što se tiče nastavnika iz obrazovne discipline, to bi mogla biti posljedica njihova mišljenja da su već stekli odgovarajuće znanje o nastavnom procesu. Također smatraju da su već stekli određenu stručnost za vođenje nastave u osnovnoj ili srednjoj školi ili u oblicima obrazovanja odraslih, što smatraju odgovarajućim i dovoljnim za vođenje nastave na institucijama visokog obrazovanja.

Osim toga, saznali smo da se nastavnici iz različitih disciplina razlikuju u određenoj mjeri s obzirom na način na koji sagledavaju kvalitetu vlastite nastave (u najširem 
smislu). Općenito, nastavnici smatraju da je njihova nastava prilično kvalitetna, a nastavnici mekih znanosti, u usporedbi s nastavnicima određenih tvrdih znanosti (pogotovo prirodnih znanosti), smatraju da je kvaliteta njihove nastave nešto bolja. Nadalje, željeli smo istaknuti najvažnije razlike među nastavnicima iz različitih disciplina s obzirom na njihove percepcije i stavove prema nastavi općenito, kao i prema sudjelovanju u pedagoškoj izobrazbi. Dobiveni rezultati idu u prilog svim prijašnjim spoznajama da nastavnici mekih znanosti imaju bolje stavove prema pedagoškoj izobrazbi i nastavi na sveučilišnoj razini nego nastavnici tvrdih znanosti, no treba još jednom istaknuti da su te razlike relativno male. Te spoznaje su barem djelomično u skladu s načinom na koji su Neumann i suradnici (2002) opisali razlike među nastavnicima tvrdih, čistih, mekih i primijenjenih znanosti, jer nastavnici mekih znanosti općenito provode više vremena pripremajući se za nastavu. To bi moglo barem malo utjecati na njihovu percepciju vlastite nastave, kao i na njihove stavove prema pedagoškoj izobrazbi, što bi ujedno predstavljalo put prema boljoj organizaciji i provedbi predavanja i prema boljoj kvaliteti nastave na sveučilišnoj razini općenito.

\section{Zaključci}

U skladu s našim rezultatima možemo zaključiti da postoji prilično jasna razlika između nastavnika mekih i nastavnika tvrdih znanosti (osim u poddisciplini zdravstvo) s obzirom na sudjelovanje i s obzirom na stavove prema nastavi na sveučilišnoj razini i prema pedagoškoj izobrazbi. Stoga možemo tvrditi da se, u određenoj mjeri, naši rezultati podudaraju s rezultatima nekih drugih autora (Adams, 1976; Batanero i Carmen, 2007; Becher i Towler, 2001; Biglan, 1973; Carril, Sanmamed, i Sellés, 2013; Costa, 2010; Kolari i Savander-Ranne, 2002; Neumann i sur., 2002; Nevgi i sur., 2004; Pleschova i Simon, 2009; Smart i Elton, 1982; Stoecker, 1993) čija su istraživanja uglavnom bila usredotočena na karakteristike nastavnika iz određenih disciplina ili na učestalije razlike među nastavnicima iz različitih discipina. U našem slučaju najuočljivije razlike pronađene su u bihevioralnoj dimenziji nastavnika (sudjelovanje u pedagoškoj izobrazbi), zatim u dimenziji koja obuhvaća stavove (njihovi stavovi prema pedagoškoj izobrazbi, kao i važnosti kvalitete nastave na sveučilišnoj razini općenito). Osim toga, postoje također i značajne, ali male razlike u perceptivnoj dimenziji nastavnika, koja uključuje nastavničke percepcije o kvaliteti vlastite nastave.

Međutim, potrebno je istaknuti značajno ograničenje našeg istraživanja, jer su svi rezultati $i$ analize utemeljeni samo na podatcima prikupljenima putem online upitnika, bez detaljnijih objašnjenja samih nastavnika i interpretacije njihovih predodžbi. Očita razlika u stavovima između predavača mekih i tvrdih znanosti trebala bi se kasnije analizirati u kontekstu faktora koji leže u pozadini, što može biti povezano sa statusom pojedinih disciplina. Status može biti povezan s različitim društvenim percepcijama nastavnika iz različitih disciplina, ili s kodovima znanja itd. Također, rezultati se ne mogu generalizirati i primijeniti na populaciju visokog obrazovanja izvan granica Slovenije. U daljnjim bi istraživanjima bilo dobro provesti kvalitativne intervjue 
sa sveučilišnim nastavnicima iz različitih disciplina kako bi se detaljnije dopunili postojeći podatci s njihovim objašnjenjima o načinu na koji percipiraju različite elemente nastave na sveučilišnoj razini i pedagošku izobrazbu, uključujući društvene percepcije, kodove znanja itd. Osim toga, širenje istraživanja na druge države moglo bi pružiti detaljniji uvid u pozadinu očitih razlika među sveučilišnim nastavnicima iz različitih discipina.

Iako se naše istraživanje temelji uglavnom na mišljenjima nastavnika o nastavi na sveučilišnoj razini i pedagoškoj izobrazbi koji su dobiveni putem upitnika, smatramo da ono već donosi važne implikacije za izradu politike i da ima dodatnu vrijednost $u$ izradi različitih institucionalnih i nacionalnih politika, standarda, regulacija i konkretne prakse u području (kvaliteti) nastave na sveučilišnoj razini, uključujući i stručno usavršavanje nastavnog osoblja. Kako se mogu uočiti razlike među nastavnicima iz različitih disciplina u bihevioralnoj i perceptivnoj dimenziji te dimenziji koja obuhvaća stavove prema pedagoškoj edukaciji i nastavi na sveučilišnoj razini, ovo drugo trebalo bi biti uzeto u obzir barem kada se uvodi i provodi pedagoška izobrazba za nastavnike iz različitih disciplina na institucionalnoj ili nacionalnoj razini. 